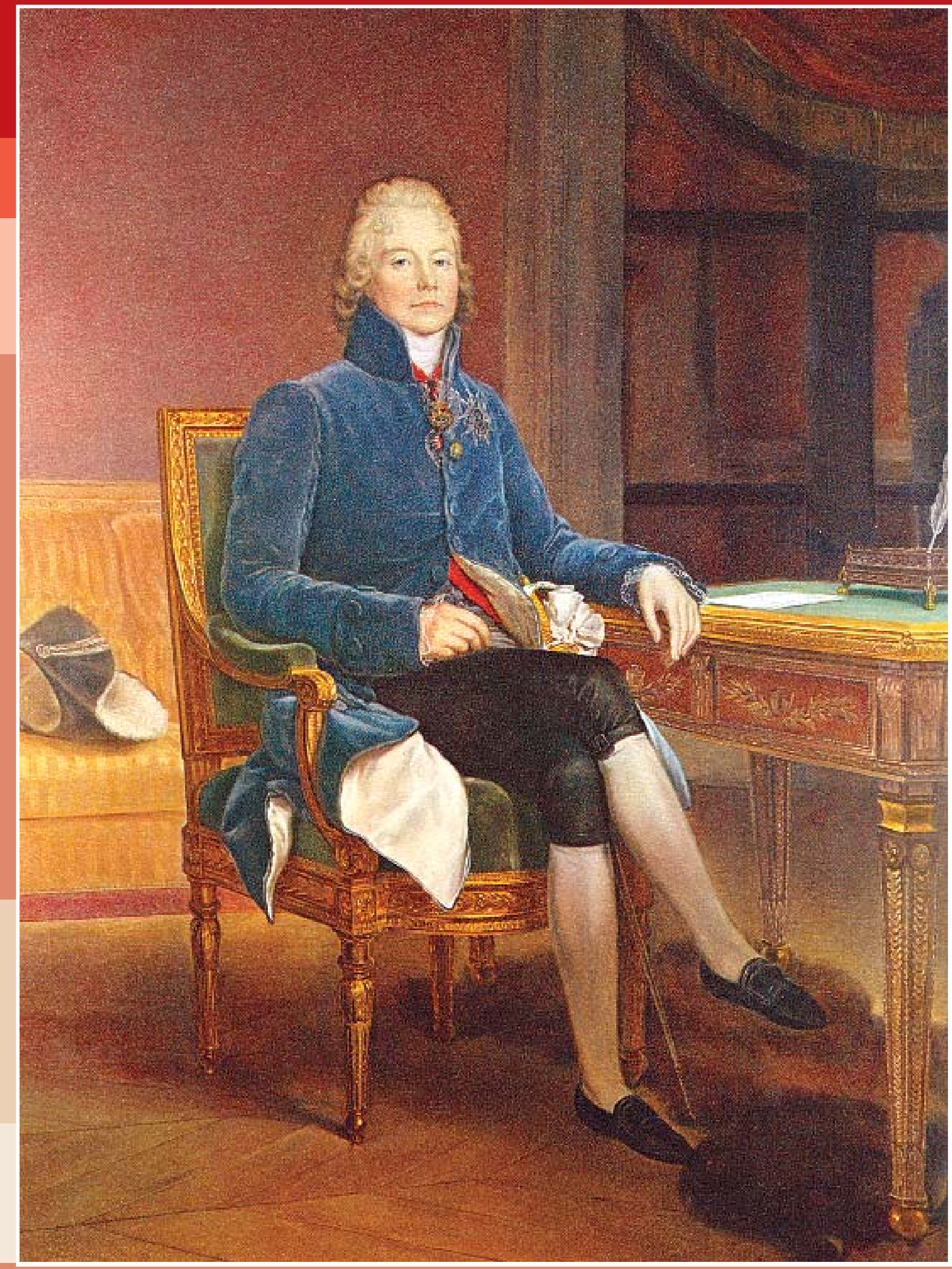




\section{Слуга многих господ -}
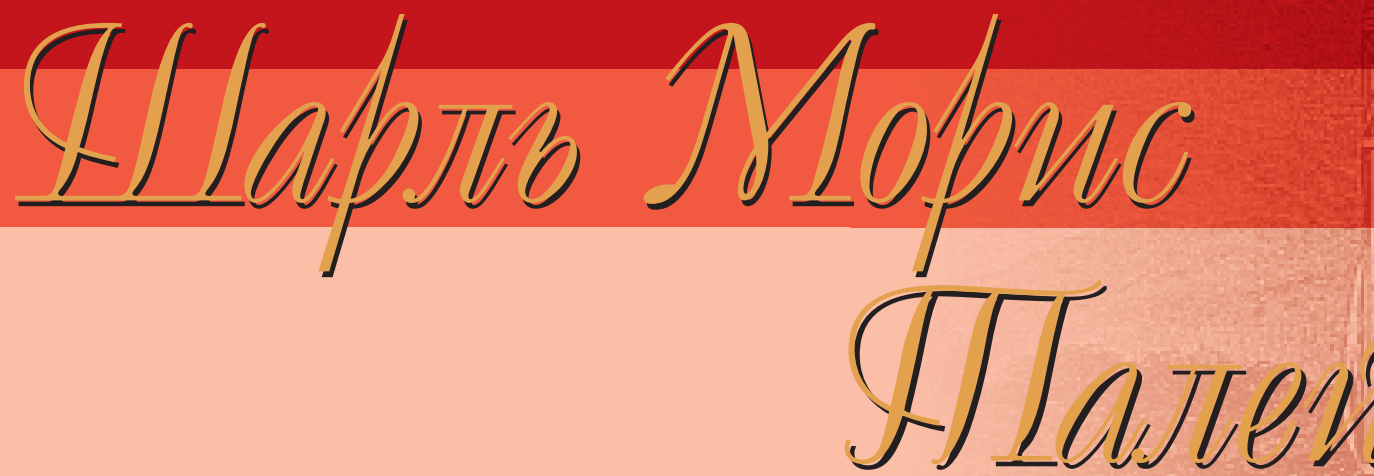

«..Я никогда его не видел даже на портрете. Бронзовое лицо, мраморная доска, на которой железными буквами написана необходимость. Я никогда не мог понять, почему люди всех времен так не понилали этого человека! Что они порицали его, это хорошо, но слабо; добродетельно, но неразумно; эти порицания делают честь человечеству, но не людям. Талейрана упрекали за то, что он последовательно предавал все партии, все правительства. Это правда: он от Людовика ХИІ перешел к Республике, от нее - кдиректории, от последней -

кКонсульству, от Консульства - кНаполеону, от него - кБурбонам, от них - корлеанам, u, может быть, до своей смерти от ЛуиФилиппа снова перейдет к Республике. Но он вовсе не предавал их всех: он только покидал их, когда они умирали. Он сидел у одра болезни каждого времени, каждого правительства, всегда шупал их пульс u прежде всех замечал, когда их сердие прекрашало свое биение. Тогда он спешил от покойника к наследнику, другие же продолжали еще короткое время служить mpуnу. Разве это измена?» - таким вопро-

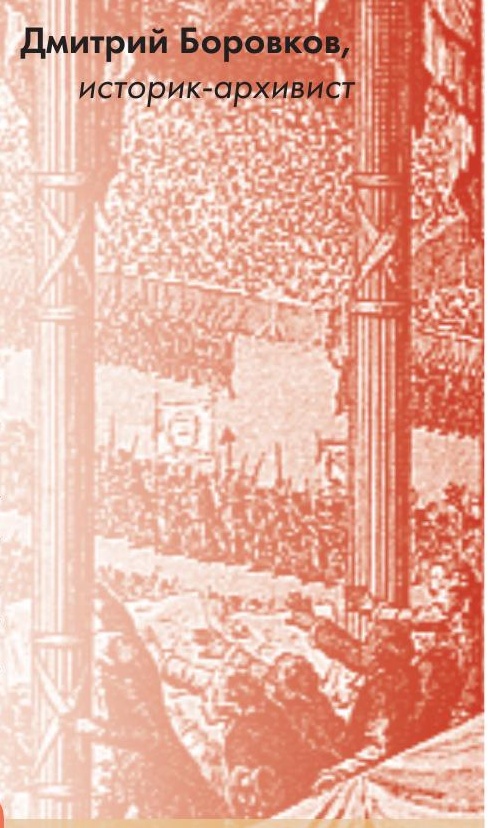

«...Он сидел у одра болезни каждого времени, каждого правительства, всегда щупал их пульс и прежде всех замечал, когда их сердце прекращало свое биение. Тогда он спешил от покойника к наследнику, другие же продолжали еще короткое время служить трупу. Разве это измена?» 


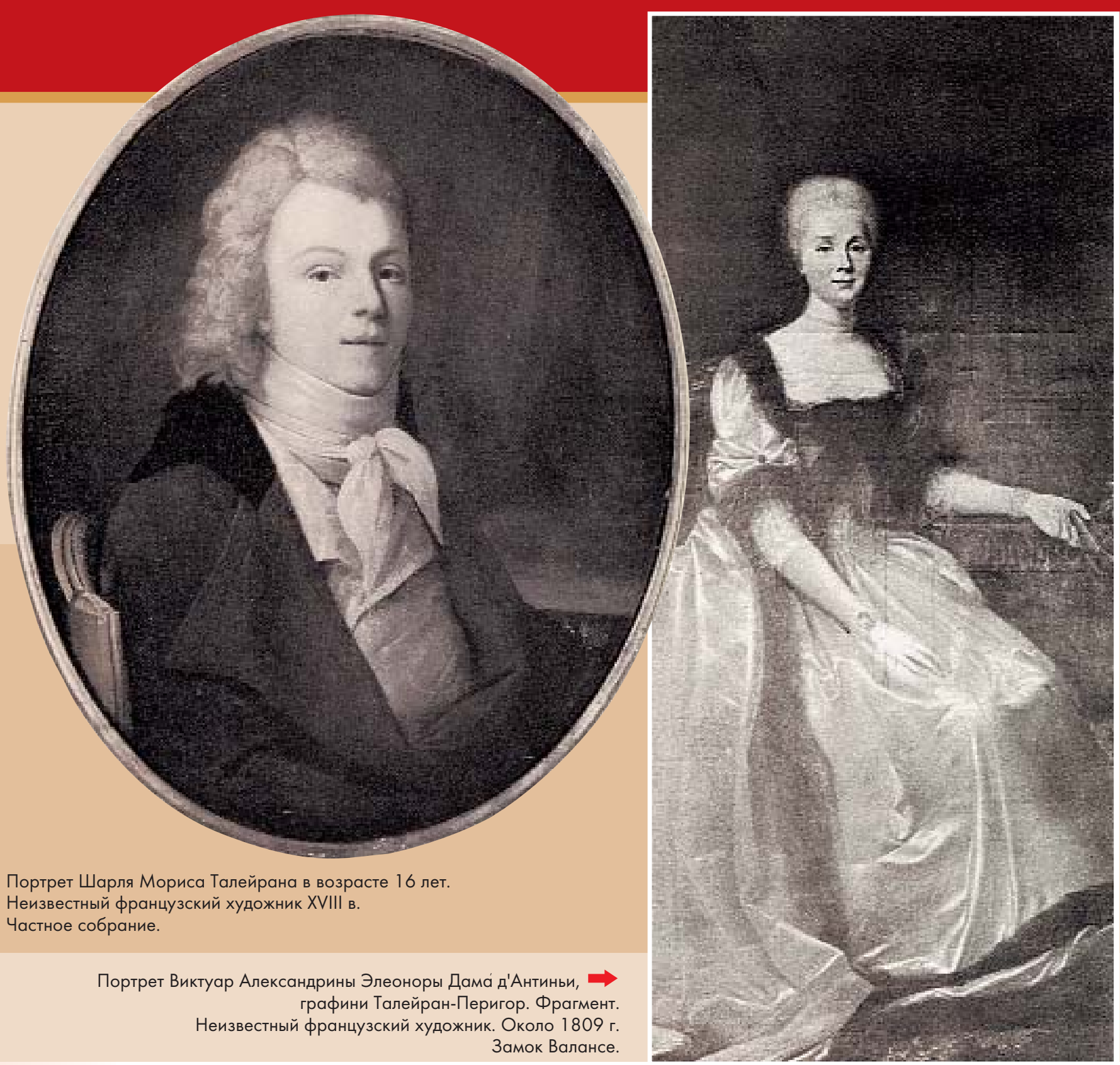

сом в 1831 г. задавался немецкий публицист Карл Людвиг Берне, пытаясь охарактеризовать противоречивую деятельность одного из крупнейших дипломатов своего времени - Шарля Мориса Талейрана-Перигора.

Шарль Морис Талейран родился 2 февраля 1754 г. в Париже в древней аристократической семье - его отец Шарль Даниэль носил несколько феодальных титулов, но был не богат, поэтому он, как его жена Александрина Дама́-Антиньи и его мать, был поглощен службой при королевском дворе. До четырехлетнего возраста Шарль Морис находился на воспитании в семье кормилицы, где с ним произошел несчастный случай: однажды он упал с комода и повредил ногу, однако кормилица не обратила на эту травму внимания и когда через несколько месяцев родители приехали забрать сына от кормилицы, оказалось, что конечность деформировалась, а травма негативно отразилась даже на здоровой ноге; оставшись хромым на всю жизнь, он был вынужден при ходьбе опираться на трость и носить специальные ортопедические сапоги. В мемуарах Талейран вспоминал: «Случай этот оказал влияние на всю мою жизнь. Благодаря ему мои родители, считая, что я не могу сделаться военным безущерба для своей каръеры, решили подготовить меня к другой деятельности. Дело в том, что в знатных семьях любили гораздо больме род, чем отдельных лии, особенно молодых, которые были еще неизвестны» - пояснял Талейран своим читателям, добавляя: «Мне неприятно останавливаться на этой мысли... я оставляю ее». Однако он все-таки еще вернется к этому, больному для него вопросу, и напишет: «...мое воспитание было в некоторой степени предоставлено случаю; это происходило не от равнодушия, но от того направления ума, которое позволяет думать, что прежде всего надо поступать и быть как все». 


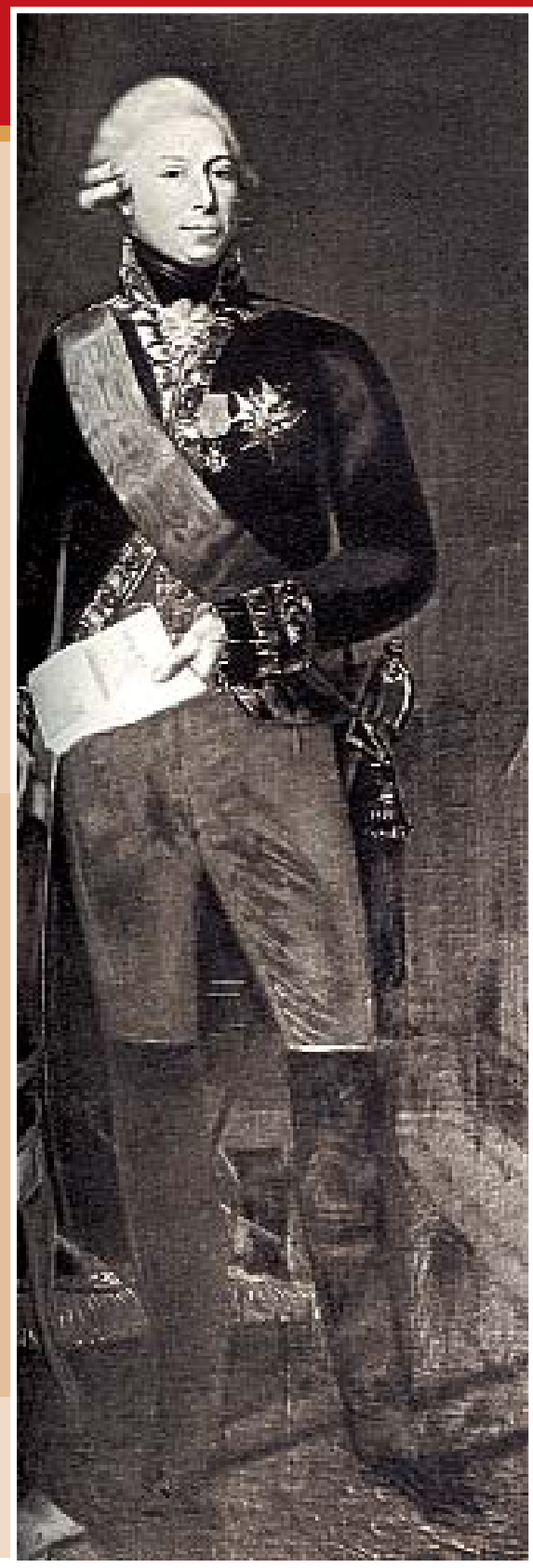

Таким образом, Талейран оправдывал недостаток внимания к его воспитанию ссылкой на своеобразие «духа времени». Самые теплые воспоминания детства он сохранил о своей прабабке Марии Франсуазе Рошешуар (в мемуарах Талейран называет ее «госпожа Шале» - по названию принадлежавшего ей замка, где он провел несколько лет), которая приходилась внучкой Жану Батисту Кольберу - министру «Короля-Солнце» Людовика XIV. В замке Шале Талейран впервые прикоснулся к феодальному миру, который через три десятилетия станет именоваться миром «Старого порядка», и достаточно подробно описал нра-

Портрет Шарля Даниэля, графа Талейрана-Перигора. Фрагмент. Неизвестный французский художник. Начало XIX в.

Замок Валансе.

Внизу:

Здание бывшего Епископского дворца в Отене. Фотография конца XIX в.

\section{Когда через несколько месяцев родители} приехали забрать сына от кормилицы, оказалось, что конечность деформировалась, а травма негативно отразилась даже на здоровой ноге; оставшись хромым на всю жизнь, Шарль Морис был вынужден при ходьбе опираться на трость и носить специальные ортопедические сапоги.

вы провинциальной аристократии предваряя это описание замечанием: «Несколько дворян древнего происхождения создавали моей бабушке своего рода двор, который не имел ничего общего с вассальной зависимостью ХІІІ века, но где почтительные нравы сочетались с самыми возвышенными чувствами..." и заканчивая его признанием: «В Шале я научился всему, что знали там люди хорошего воспитания; это сводилось куменъю читать, писать и немного говорить на перигорском диалекте». Вооруженного этими знаниями Талейрана родители вызвали в Париж и поместили в одно из старейших учебных заведений Франции - Коллеж Гаркура, основанный в конце XIII в., где в то время воспитывался один из его родственников. Талейран пишет: « был поражен тем, что меня так внезапно отдали в коллеж, не привезя предварительно котиу и кматери. В период обучения в Коллеже Горкура его общение с семьей сводилось к тому, что раз в неделю в сопровождении своего наставника, аббата Гарди, ходил обедать в дом своего отца: «о выходе из-за стола мы возврамались в коллеж, выслушивая регулярно одни и те же слова: «Будьте послушны, мой сын, чтобы господин аббат был вами доволен" - вспоминал Талейран. В двенадцать лет он заболел оспой и был вынужден на некоторое время по-

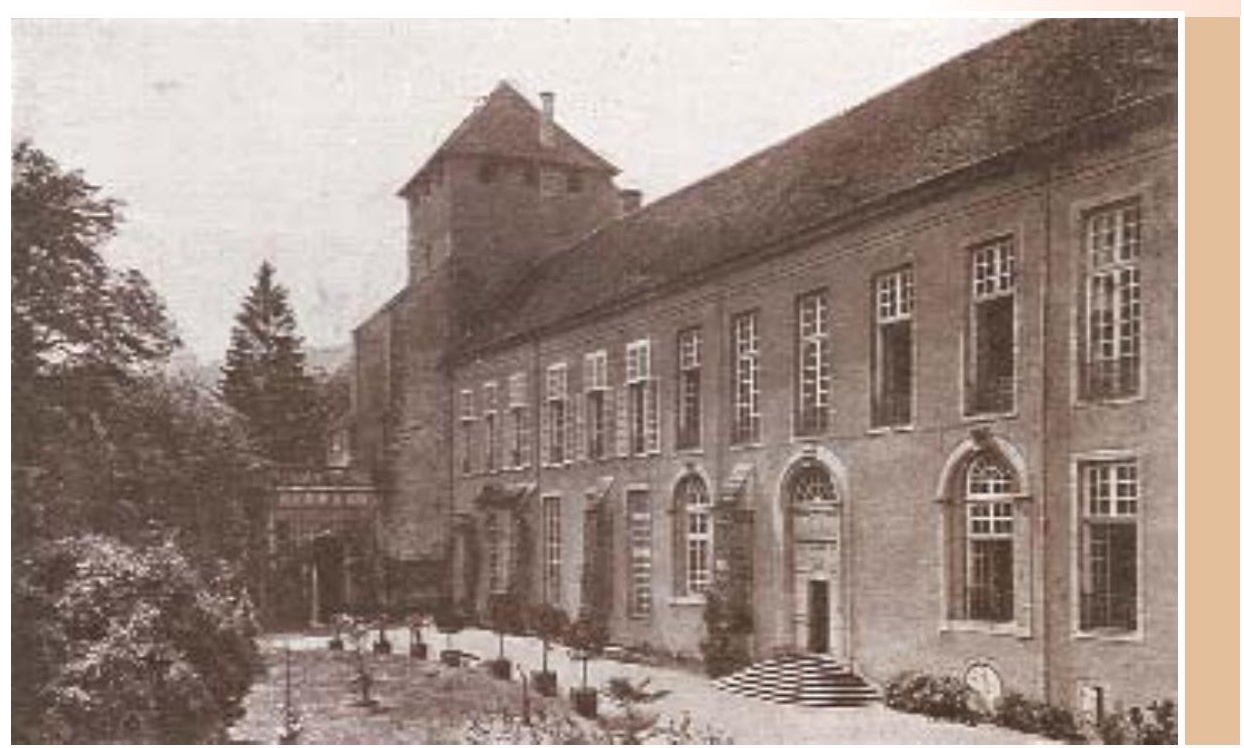



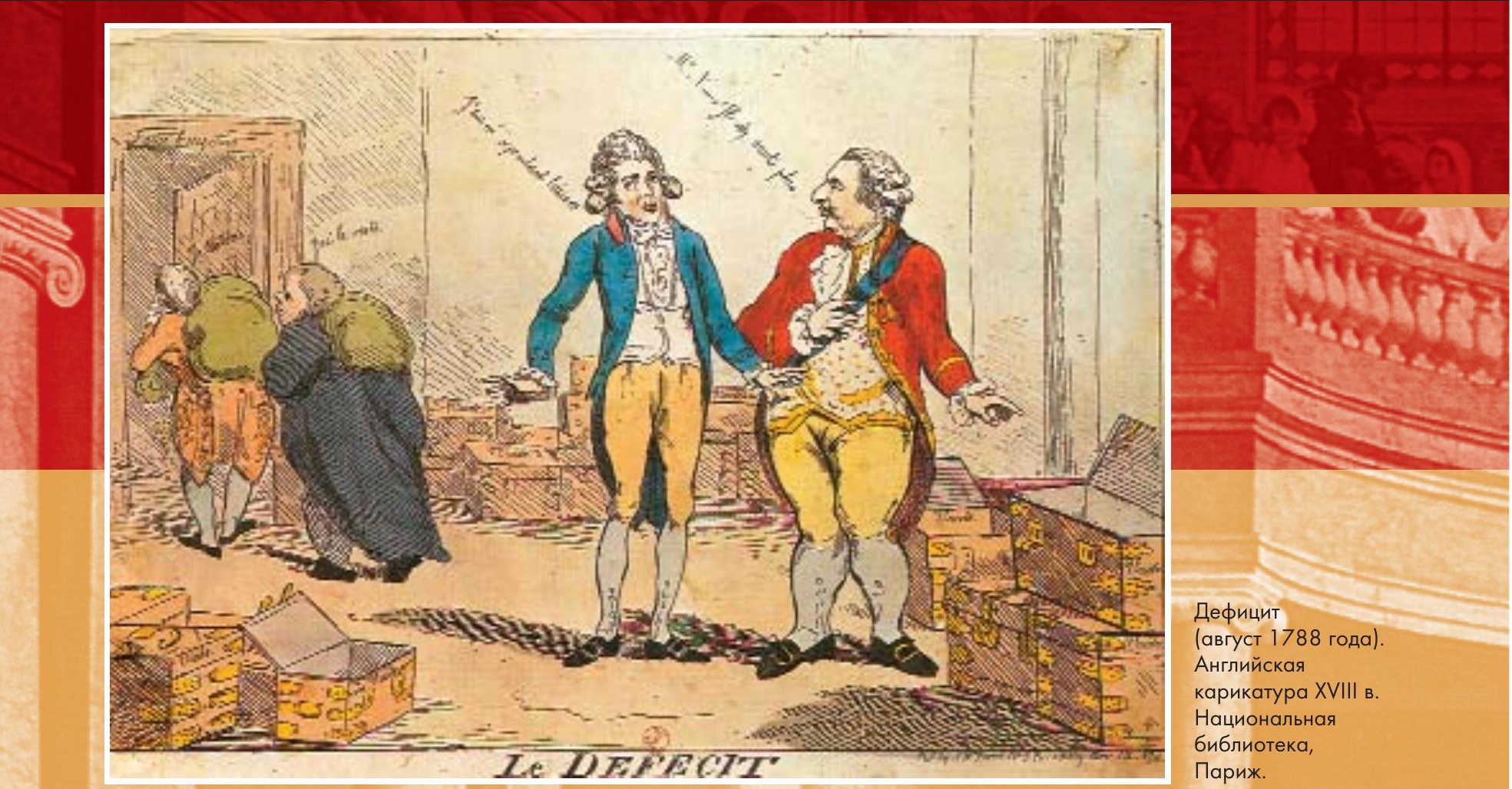

кинуть Коллеж, его отдали под присмотр наемной сиделки. «Малый интерес, проявленный к моей болезни, поступление в коллеж без свидания с родителями и некоторые другие печальные воспоминания оскорбляли мое сердие» - признавался Талейран в своих воспоминаниях и, смешивая эмоции с ретроспективными оценками, продолжал: « чувствовал себя одиноким, без поддержки, всегда предоставленным самому себе; я не жалею об этом, так как считаю, что самоуглубление ускорило развитие моих способностей к размышлению. Огорчениям своего раннего детства я обязан тем, что стал их рано развивать и усвоил привычку размыилять более глубоко, чем если бы был вполне счастлив. Возможно также, что вследствие этого я научился довольно равнодушно переносить тяжелые времена, сосредоточиваясь на своих внутренних силах, в обладании которыми я был уверен».

По окончании коллежа семья предназначила Талейрану церковную карьеру тем более что один из братьев его отца Александр-Анжелик являлся заместителем и официальным преемником престарелого архиепископа Реймсского, кардинала Шарля Антуана де ла Рош-Аймона, и должен был возглавить самую авторитетную во Франции епархию, находясь во главе которой мог бы обеспечить племяннику протекцию. По словам Талейрана, чтобы соблазнить его перспективой церковной карьеры ему давали читать то воспоминания кардинала
Реца, то жизнеописания кардинала Ришелье, испанского кардинала Хименеса или реймсского архиепископа Гинкмара. В конце концов, 16-летний юноша был вынужден поступить в семинарию святого Сульпиция, находясь в которой он практически ни с кем не общался, проводя время за чтением книг. «Библиотека семинарии св. Сульпиция, обогащенная кардиналом Флери, была обширна и хорошо составлена. Я проводил там дни за чтением великих историков, жизнеописаний государственных людей, моралистов, некоторых поэтов. Я проглатьвал путешествия.Новые земли, опасности, бури, изображение какого-нибудь бедствия, описания стран со следами великих перемен, иногда переворотов - все это обладало для меня большой привлекательностью признавался Талейран. - Порой при размышлении над этими большими переменами, этими великими потрясениями, описание которых наполняет произведения современных мореплавателей, мне казалось, что мое положение не столь непоправимо... Так как я был очень одинок, очень молчалив, всегда с глазу на глаз с автором той книги, которую я держал в руках, и так как я мог судить о нем лишь силами собственного рассудка, то почти всегда при расхождении наших взглядов я считал, что прав я. Вследствие этого мои взгляды были действительно моими: книги меня просветили, но не поработили. Я отнюдь не сужу, хорошо ли это или плохо, но только говорю,
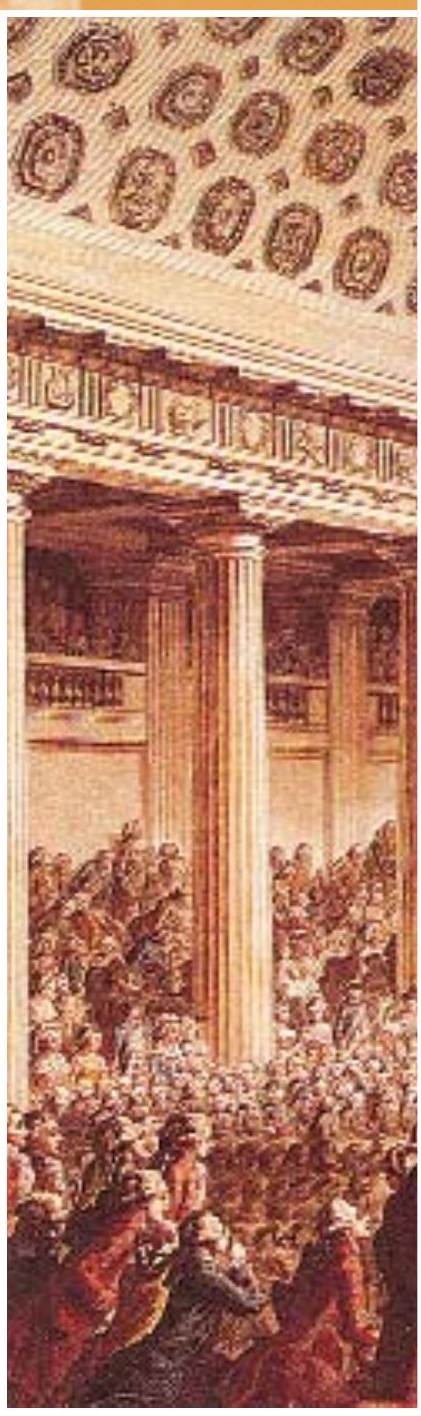
Депутаты коммуны провозглашают образование Национального собрания. Цветная гравюра XVIII в. Музей Карнавале, Париж.

Талейран вспоминал: « провел здесь два года, занятый отнюдь не теологией, так как у молодого бакалавра развлечения отнимали очень много времени». После окончания Сорбонны в 1778 г. он был назначен аббатом реймсского монастыря СенДени, а через два года все же сумел воплотить в жизнь свою мечту, хотя и в ограниченном масштабе, став генеральным агентом (казначеем) галликанской церкви при королевском правительстве. На этом посту Талейран столь энергично отстаивал церковные права и привилегии, что на генеральной ассамблее духовенства в 1785 г. получил за свои труды вознаграждение в сумме тридцати одной тысячи ливров; помимо этого он изыскивал различные источники увеличения дохода, не брезговал спекуляциями и взятками, потому как вел вполне светский образ жизни - был страстным игроком, пользовался успехом у женщин. В 1783 г. аббат Талейран познакомился с замужней графиней Аделаидой де Флао, от которой у него

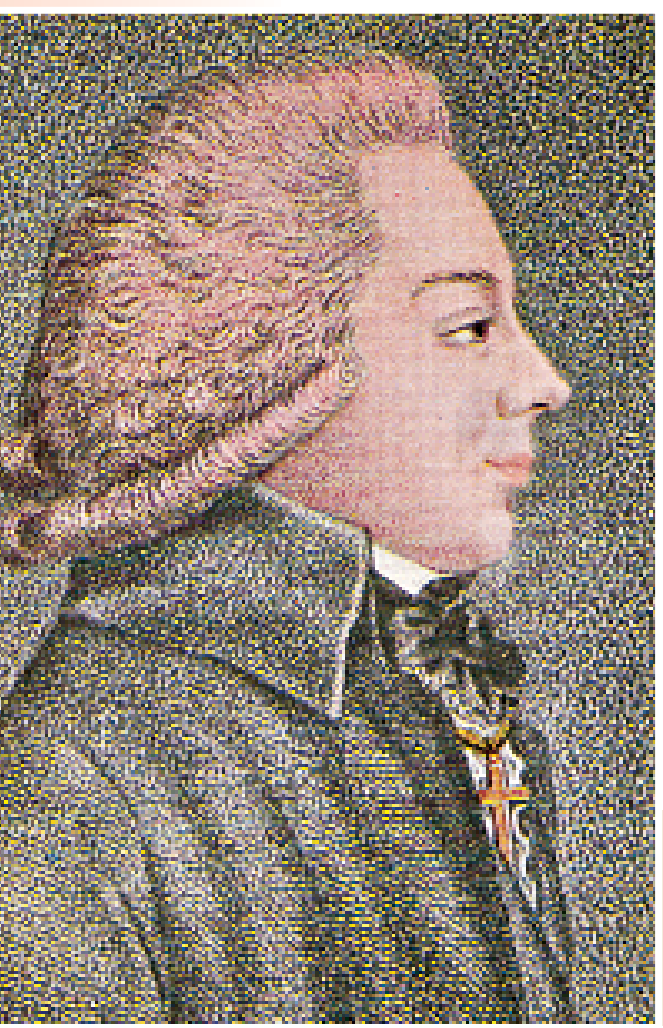

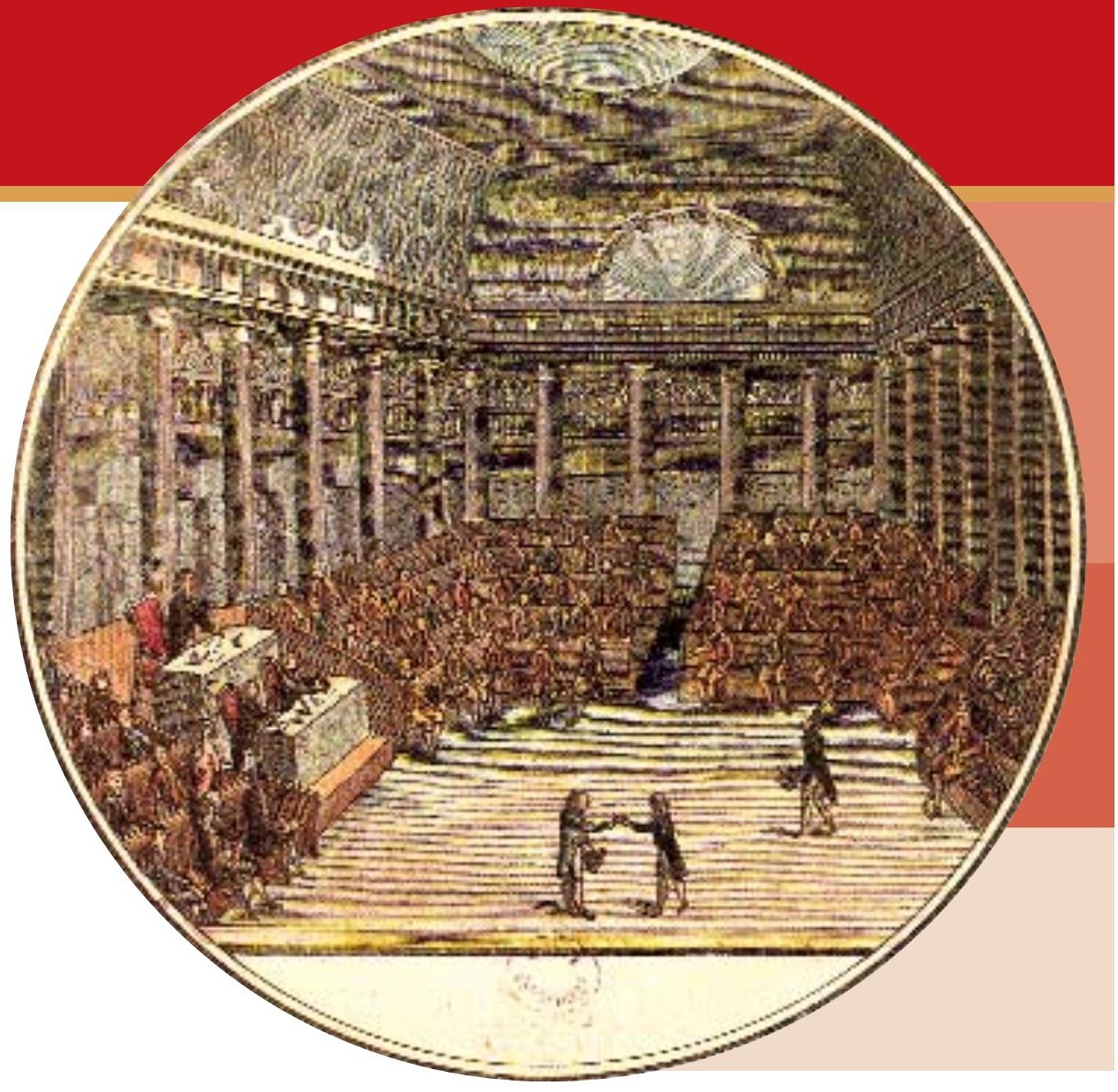

родился сын - этот ребенок, известный в анналах истории под именем Шарля Жозефа де Флао (1785-1870 гг.) сделал блестящую карьеру - при Первой империи он стал графом, генералом и адъютантом Наполеона I; при Реставрации членом палаты пэров; при Июльской монархии - послом в Берлине и Вене; при Второй империи - послом в Лондоне и великим канцлером ордена Почетного легиона.

Образ жизни Талейрана долгое время препятствовал его посвящению в епископский сан; только вмешательство отца помогло ему получить Отенское епископство, куда он был назначен в ноябре 1788 г. Епархия могла приносить Талейрану более пятидесяти тысяч ливров годового дохода, однако в ней он не задержался - в апреле 1789 г. Талейран был избран депутатом Генераль-

ных штатов от отенского духовенства и отправился в Париж. К тому времени финансовое положение Франции являлось критическим, она оказалась перед угрозой банкротства, а поскольку согласовать меры по выходу из этого положения с привилегированными сословиями на так называемом собрании нотаблей (1787 г.) не удалось, король Людовик XVI был вынужден созвать сословный парламент, в полном составе не собиравшийся 175 лет, в котором наряду с представителями духовенства и дворянства должны были присутствовать представители «третьего сословия» - буржуазии. По настоянию генерального контролера финансов Жака Неккера количество депутатов от «третьего сословия» было увеличено вдвое, поэтому именно они стали задавать тон в Генеральных

Шарль Морис Талейран-Перигор, бывший епископ Отена, депутат Национального собрания. Гравюра Ж.-Б. Верите. Около 1792 г.

Национальная библиотека, Париж. 
Образ жизни Талейрана долгое время препятствовал его посвящению в епископский сан; только вмешательство отца помогло ему получить Отенское епископство, куда он был назначен в ноябре 1788 г. Епархия могла приносить Талейрану более пятидесяти тысяч ливров годового дохода, однако в ней он не задержался - в апреле 1789 г. Талейран был избран депутатом Генеральных штатов от отенского духовенства и отправился в Париж.

штатах, открывшихся в Версале 4 мая 1789 г., и уже через полтора месяца вступили в открытое противостояние с исполнительной властью, провозгласив себя Национальным собранием (несколько позже оно переименовало себя в Учредительное собрание и принялось за разработку конституции). Талейран, в отличие от своего дяди Александра-Анжелика, ставшего к тому времени архиепископом Реймсским и высту-

Соединенными усилиями три сословия выковывают конституцию 1791 года. Раскрашенная гравюра XVIII в. Музей Карнавале, Париж.

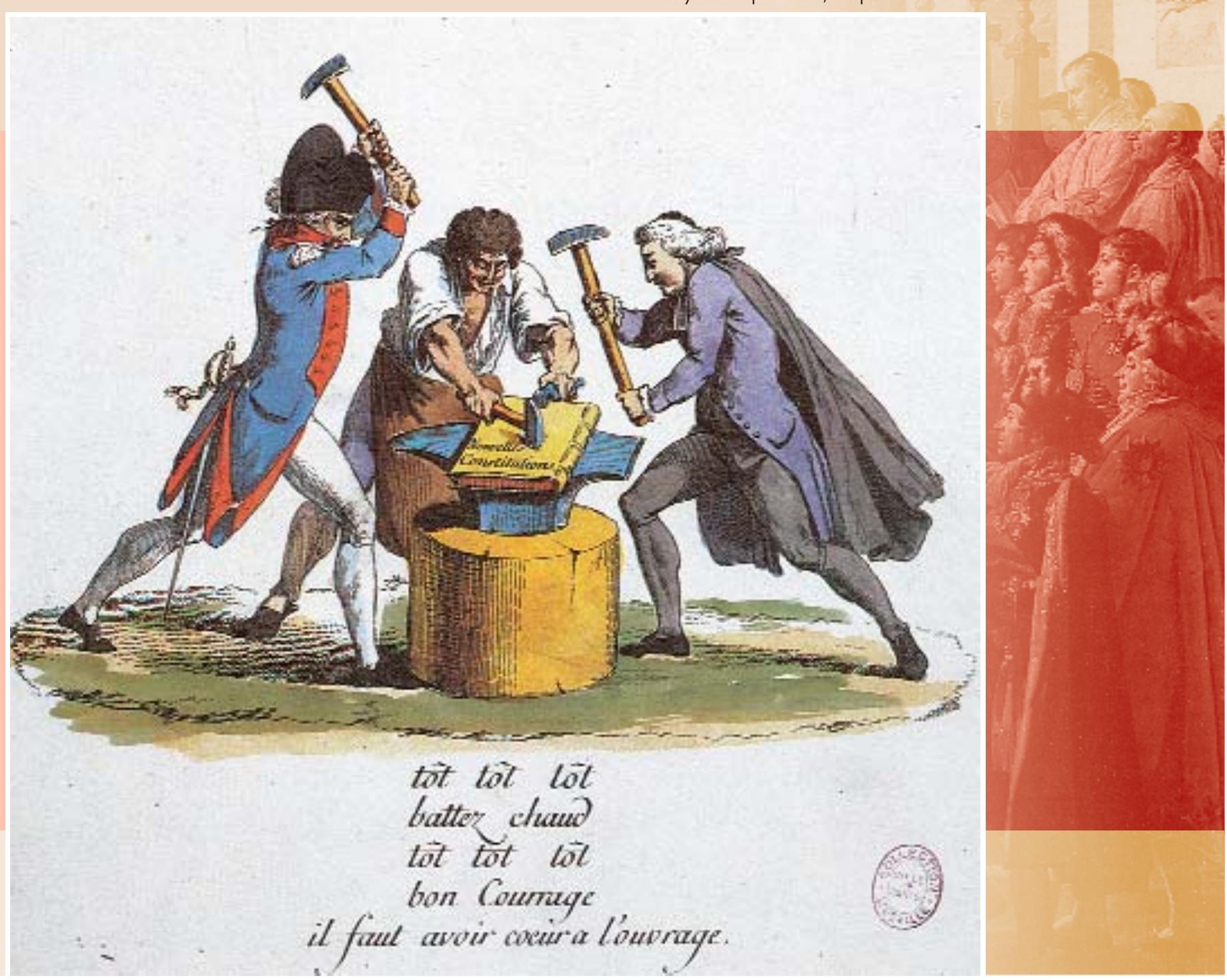




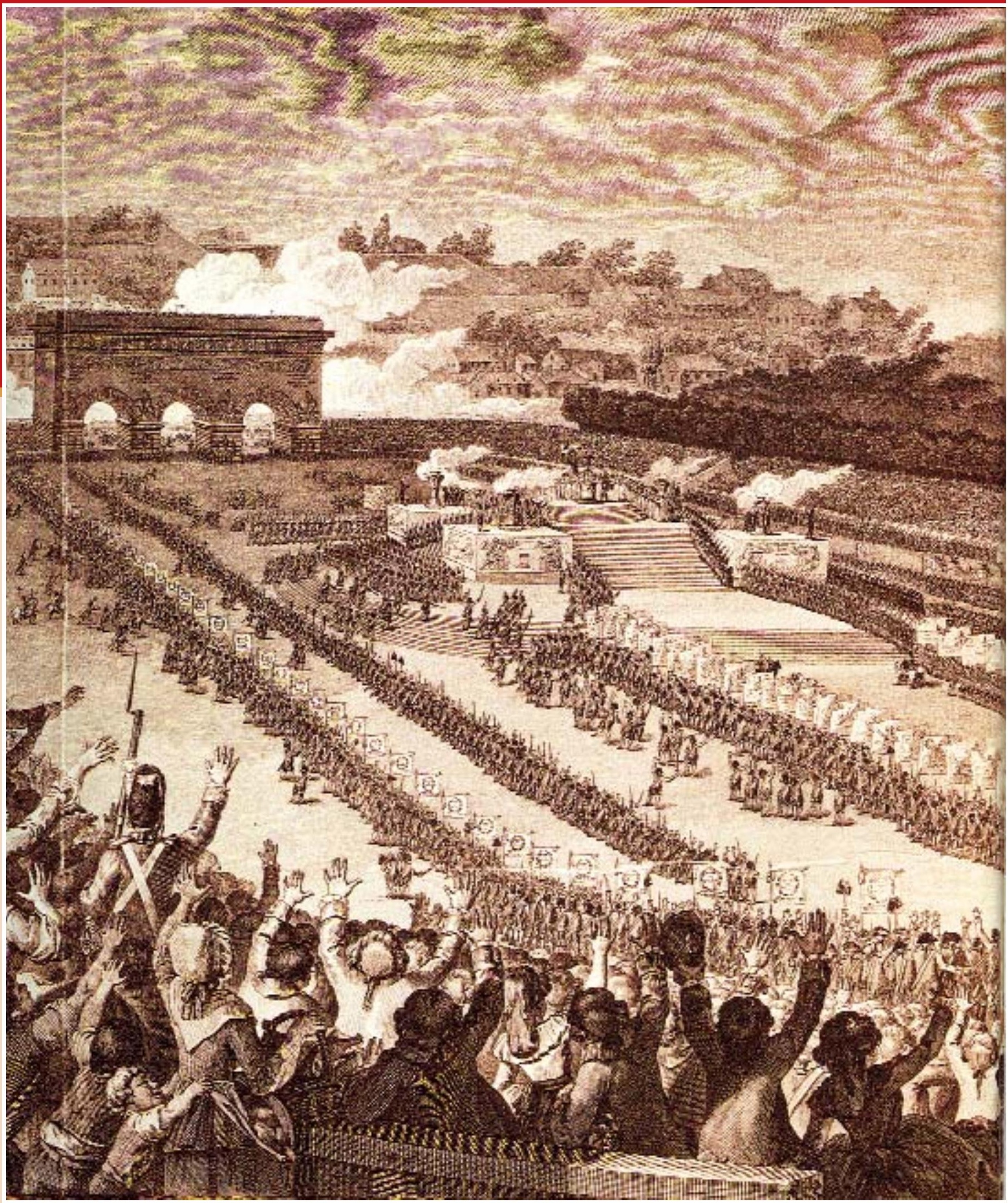

павшим в Генеральных штатах против реформ, напротив, считал, что необходимо пойти на уступки «третьему сословию», с тем, чтобы королевское правительство могло выиграть время и сохранить контроль над ситуацией. Хотя двор пытался заручиться поддержкой Талейрана в начавшейся политической игре он отверг сделанные ему выгодные предложения и сделал ставку на «третье сословие», считая его требо- вания вполне закономерными. Та лейран принял участие в составле нии «Декларации прав человека и гражданина», а через несколько дней после того как местопребывание королевского двора по требованию 


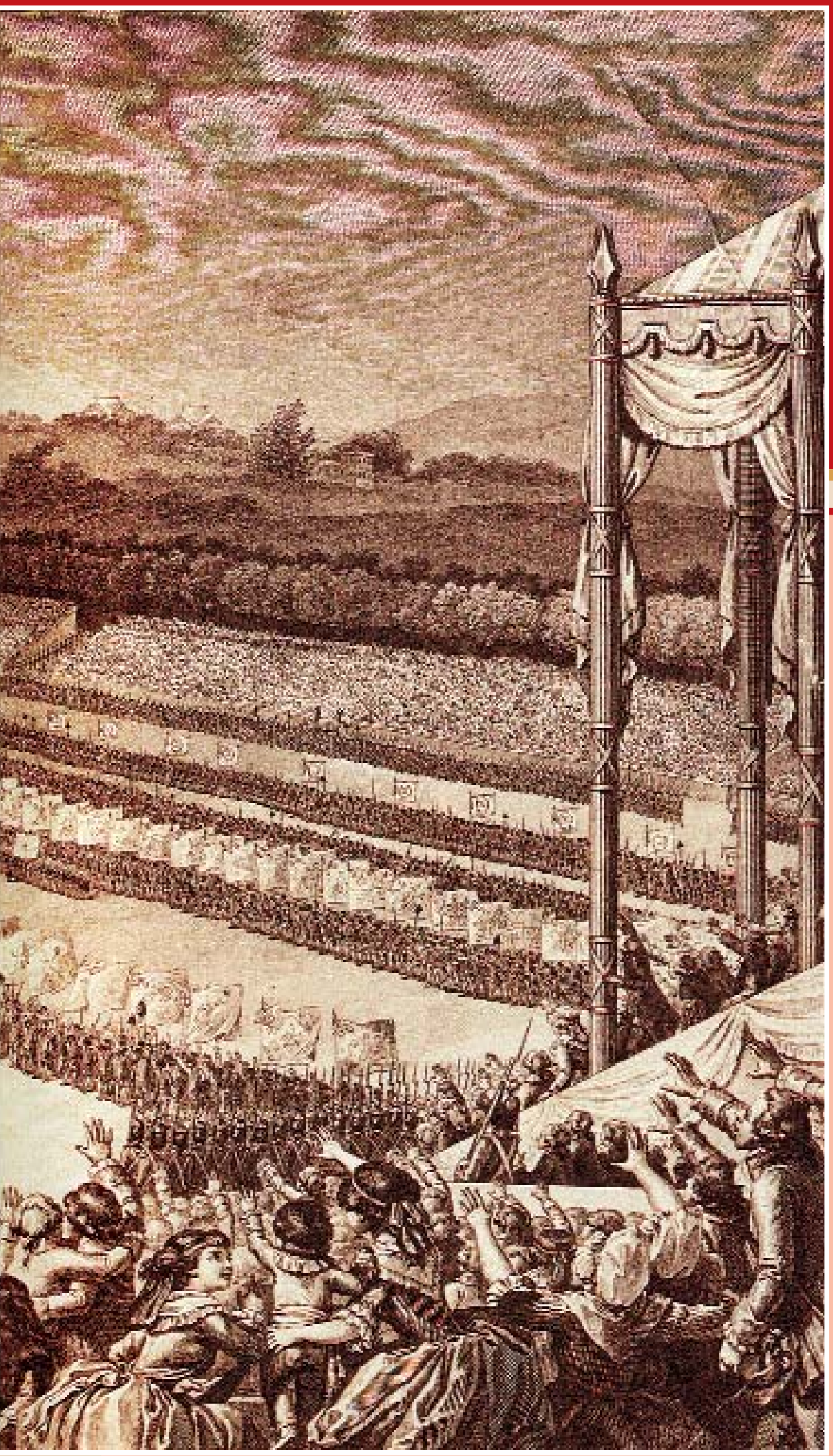

Праздник федерации. *

Гравюра И.-С. Элмана по рисунку

Ш. Монне.

Национальная библиотека, Париж.

* Идея федерации - объединения между собо й

всех коммун, всех провинций и всего французского

народа в результате революции - получила боль-

шое распространение во Франции в 1789-1790 гг.

В ряде провинций состоялись праздник Федерации.

Учредительное собрание 9 июня 1790 г. приняло

решение о проведении в Париже 14 июля, в годов-

щину революции, общенационального праздника

федерации. Для участия в этом празднике в столицу

приглашались депутаты от национальной гвардии.

жно было избрать по 6 депутатов на 100 человек.

Эти депутаты собирались в центре своего округа

и избирали по 1 делегату на каждые 200 человек

(и 400 в более отдаленных районах). В Париж сьеха-

лось несколько тысяч депутатов и представителей от

армии и флота.

«Под струями дождя шествие двигалось к алтарю отечества. Триумфиальная арка открывала дорогу на Марсово поле. Собралось несметное множество народу, но не было ни экипажей, ни лошадей, ни людей с тростями и шпагами. Посредине Марсова поля возвышался, как божий холм, алтарь отечества. В крытой части амфитеатра был воздвигнут трон короля; позади стояла королева с сыном. Справа сидел председатель Национального собрания; перед ним, в открытом амфитеатре, справа и слева, почтенные народные представители, мужи священной свободы, - сцена, возвышеннее и трогательнее которой не могла бы вообразить самая пылкая фантазия. Перед королем возвышался алтарь отечества, и по всему пути к нему выстроилась с обеих сторон парижская национальная гвардия. Бесчисленные группы музыкантов, исполнявших то воинственную, то нежную музыку, расположились на сооруженных для них помостах и аккомпанировали ликованию этого дня. В тысячах надписей и эмблем новые франки выказывали свое остроумие, высокий дух и пылкую любовь к отечеству. Близ алтаря стояли представители национальной гвардии вместе с добровольцами, а рядом с ними - поседевшие на службе родине воины. В отдалении возвышались скамьи амфитеатра, на которых помещалось более шестисот тысяч зрителей. Епископ Отена служил мессу. Небо все еще было покрыто тучами, и лил дождь. Но отбушевали металлические жерла грома, и небо опять приветливо улыбалось этой величественной сцене. На ступенях алтаря стояли священники, все в белых облачениях, опоясанные национальными лентами. Прочли слова клятвы, и мириады людей, «буре подобно ревущей, вздымающей грозные волны», закричали: «Клянусь, клянусь!»»

(К.-Ф.-Д. Шубарт, «Праздник свободных», 1790 г.) 


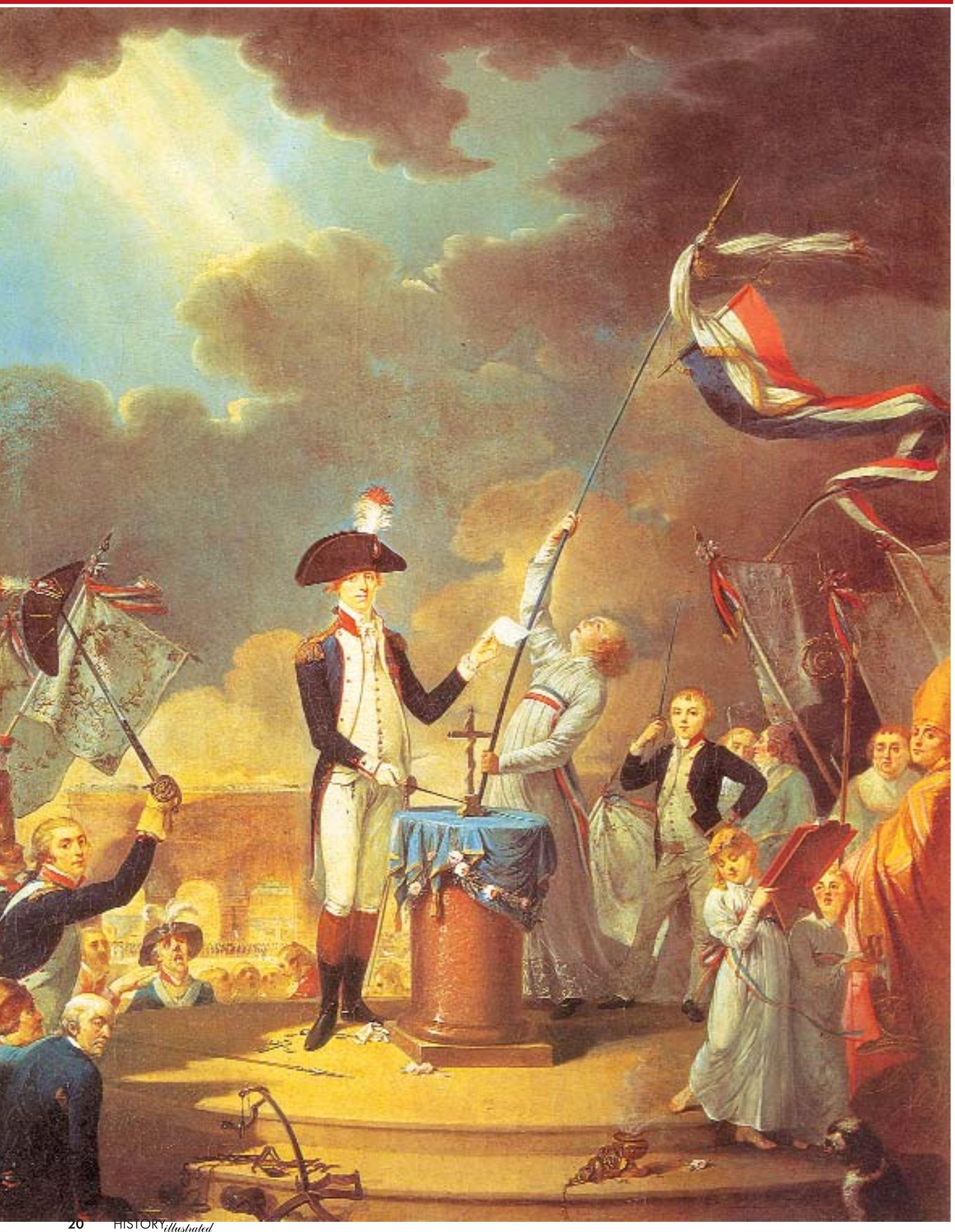


Присяга духовенства на верность Гражданской конституции в зале Учредительного собрания 28 апреля 1790 года. Гравюра XVIII в. Музей Карнавале, Париж.
Талейран еще более углубил этот разрыв, выступив с предложением превратить день взятия Бастилии в национальный праздник - в первую годовщину этого события «епископ революции» отслужил торжественную мессу на Марсовом поле, а вечером того же дня посетил два игорных дома
ива раза «сорвал банк».

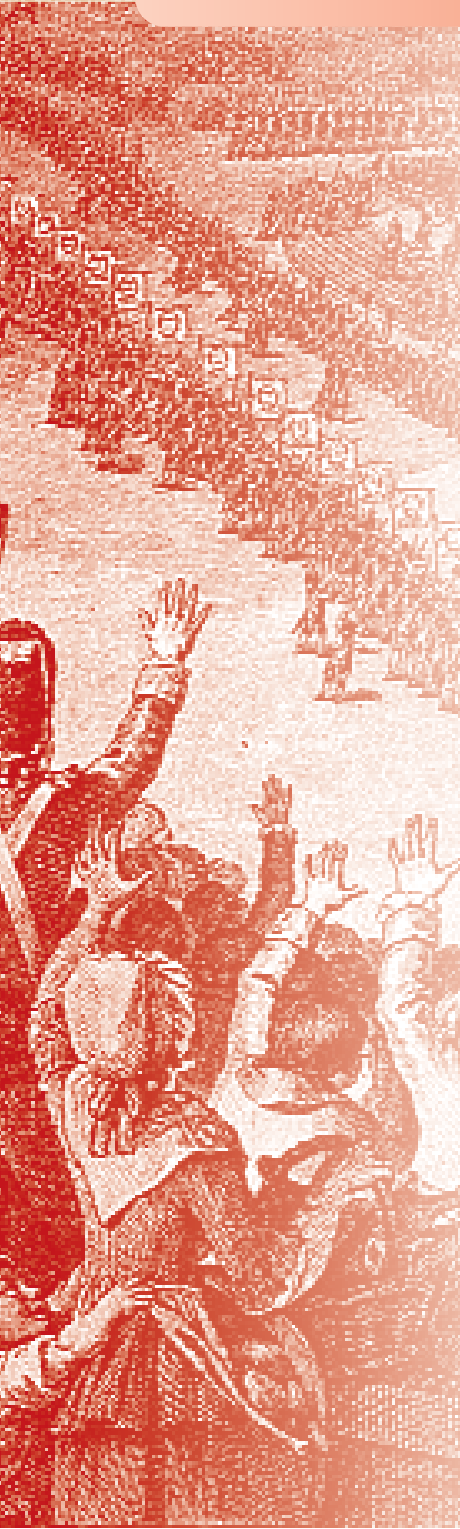
Вик д'Азир, Лагарп, и они все помогли мне».

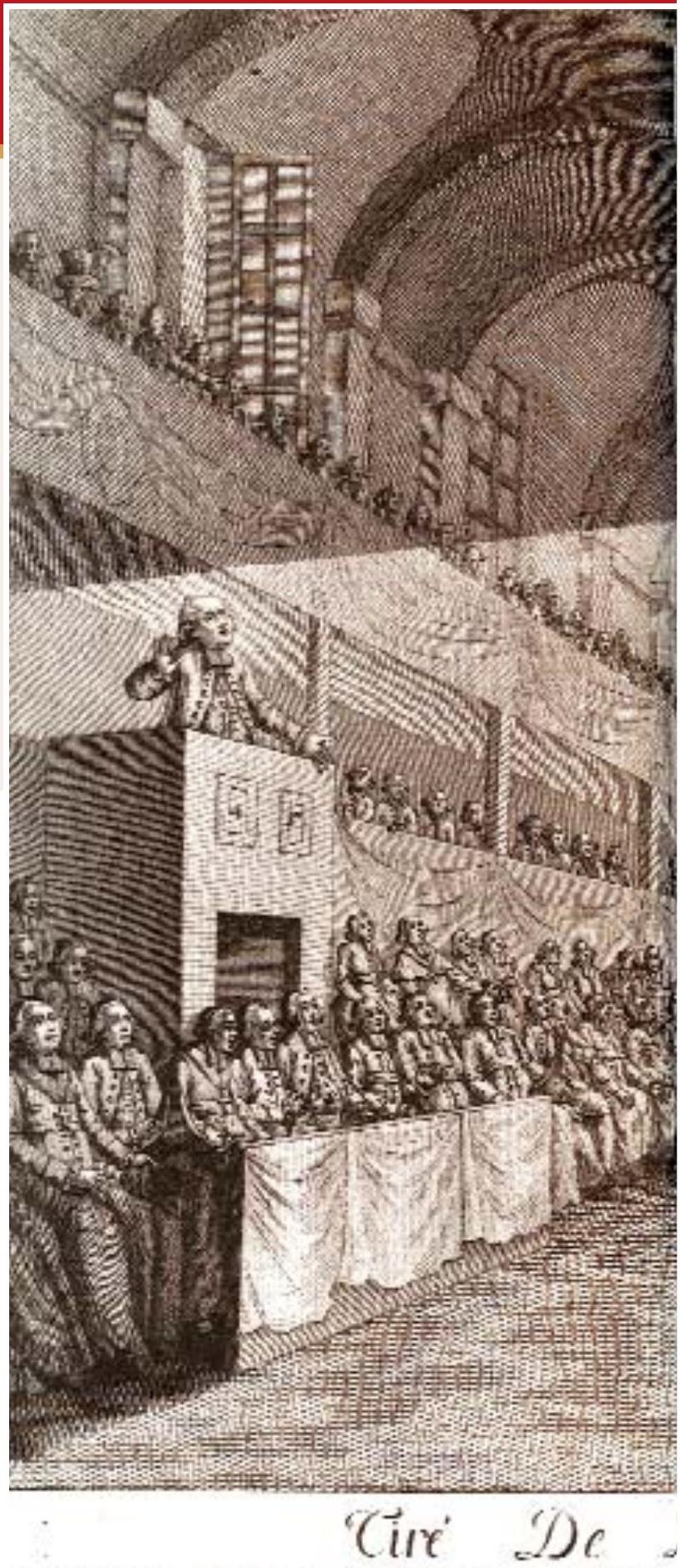

банка, унификации системы мер и весов, реформы народного образования. В мемуарах он напишет: «ля выполнения этой большой работы я обрашался за указаниями к самьм образованньм лицам и самьмм видным ученьм той эпохи, в которую жили Лагранж, Лавуазье, Лаплас, Монж, Кондорсе,

В конце 1789 г. глава Дипломатического комитета Учредительного собрания граф Мирабо, несмотря на довольно сложные отношения с Талейраном, назвал его в качестве одного из кандидатов на пост министра иностранных дел, однако назначение не состоялось, - зато в феврале 1790 г. он был избран председателем Учредительного собрания. Талейран поддержал один из наиболее амбициозных революционных проектов - подчинение церкви государству - и рукоположил первого епископа, принесшего присягу специальной конституции, после чего отправил Людовику XVI прошение об отказе от епископского сана. Римский папа Пий VI отказался признать новое устройство галликанской церкви и провозгласил отлучение Талейрана. Разрыв с Римом позволил ему целиком сконцентрироваться на политической деятельности. В апреле 1791 г. после смерти Мирабо он занял его место во главе Дипломатического комитета и, таким образом, стал своего рода «парламентским министром». Талейран уже имел некоторый опыт в этой сфере, так как еще при жизни Мирабо был причастен к дипломатическим

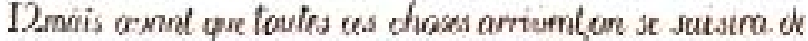

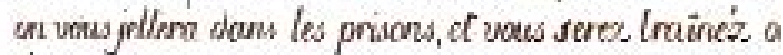

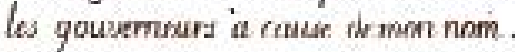

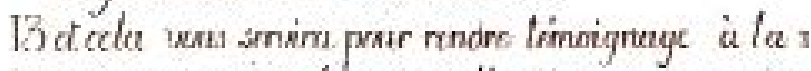

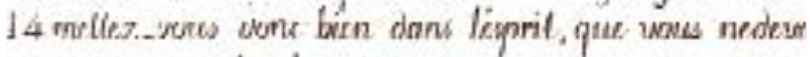
Nows hurre a rependire.

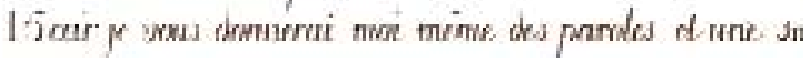

контактам последнего с русским посольством в Париже. В 1792 г. состоялась первая зарубежная «командировка» Талейрана в Лондон, где он должен был обеспечить революционной Франции нейтралитет анг- 


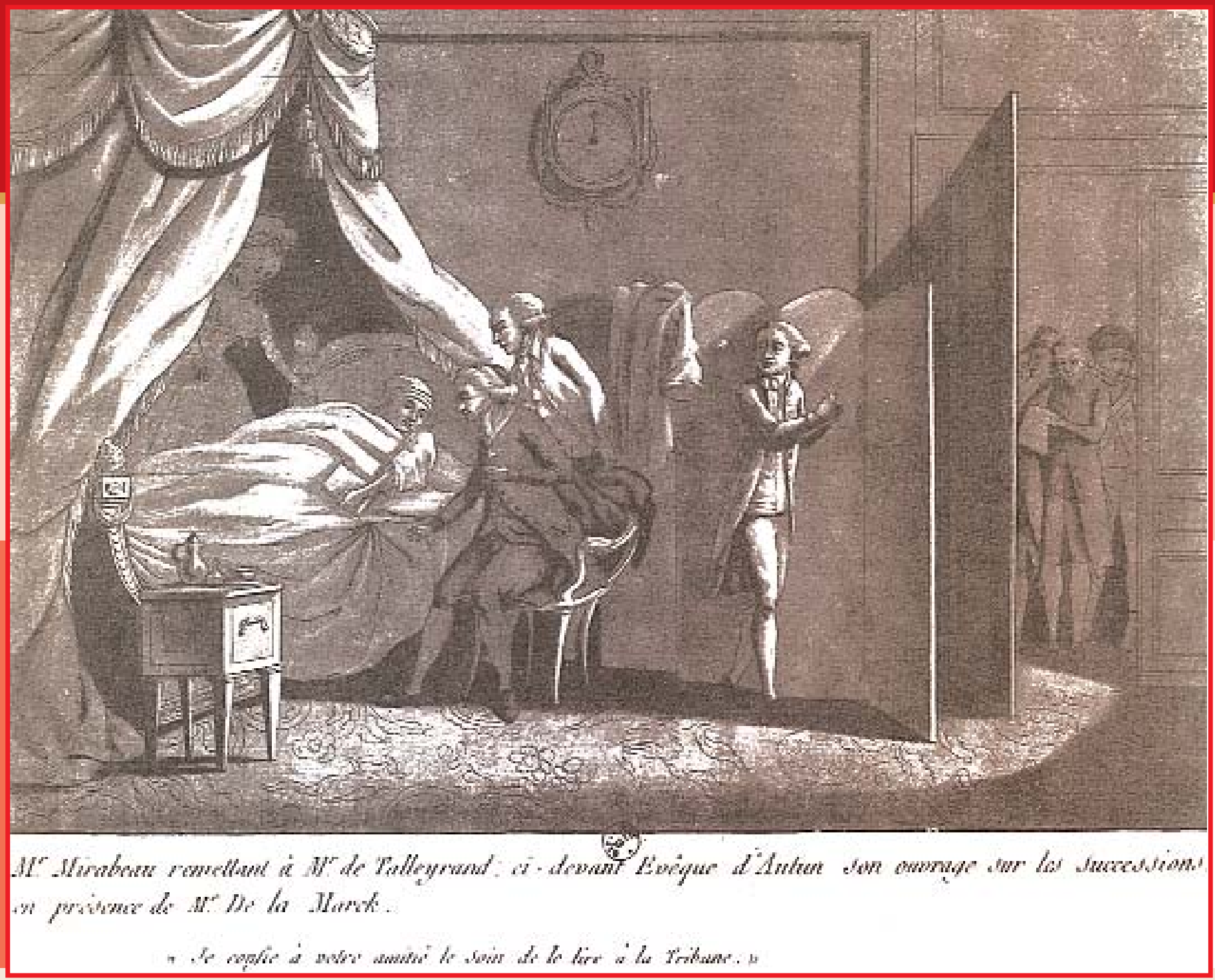

Смерть Мирабо («Г-н Мирабо передает г-ну Талейрану, епископу Отенскому, свой труд о наследовании в присутствии г-на Де ла Марка»). Гравюра XVIII в. Национальная библиотека, Париж.

напротив, стремился обосновать перед европейским «общественным мнением» необходимость свержения короля, мотивируя этот акт тем, что он «нечувствительно подкапьвался под новую конституиию, в которой ему было отведено такое прекрасное место». Через месяц после этого он вновь отправился в «командировку» в Англию под предлогом унификации метрической системы, с трудом раздобыв паспорт после ужесточения революционным правительством правил выезда за границу, и... стал «невозв-

\section{Римский папа Пий VI отказался признать} новое устройство галликанской церкви и провозгласил отлучение Талейрана. Разрыв с Римом позволил ему целиком сконцентрироваться на политической деятельности. В апреле 1791 г. после смерти Мирабо он занял его место во главе Дипломатического комитета и, таким образом, стал своего рода «парламентским министром».

ращенцем». Свой поступок Талейран прокомментировал следующим образом: «...Моей истинной целью было уехать из Франции, где мне казалось бесполезньм и даже опасньи оставаться, но откуда я хотел уехать только с законныи паспортом, чтобы не закрыть себе навсегда пути к возвращению". Талейран не говорит конкретно о причине, вынудившей его эмигрировать, но она была достаточно веской: «дело в том, что в знаменитом «железном шкафу» короля, 
Открытие знаменитого «железного шкафа» в Тюильри. Гравюра XVIII в.

Перед ошеломленным взглядом министра Ролана из открытого икафа с секретными документами появляется призрак Мирабо. На овальнои портрете изображен Людовик ХVI в виде зиеи, извергающей свой яд во фригийский колпак. Внизу: Французская карикатура конца XVIII в. Национальная библиотека, Париж.

В 1790-х годах франтов, одевающихся чрезмерно модно, франиузы называли «невероятными" (Incroyable). Характерной деталью франиузских денди того времени был широкий шейный платок практически закрываюший рот. Фрак экстрава -

гантного покроя дополнялся цветастым жиле том с иирокими бортами и брюками до колен

скисточками.

вскрытом по приказу револющионного правительства, оказались два документа, доказывавиие, что еше весной 1791 г. Талейран тайно предлагал королю свои услуги... - свидетельствует его биограф академик Е.В. Тарле. Само собой разумеется, ловкий политик пошел на такой риск не просто так, а рассчитывая заслужить «благодарность» двора, выраженную в звонкой монете, однако тем самым он дискредитировал себя в глазах революционного правительства, которое 5 декабря 1792 г. объявило Талейрана эмигрантом (его имущество было конфисковано и позднее продано с торгов).
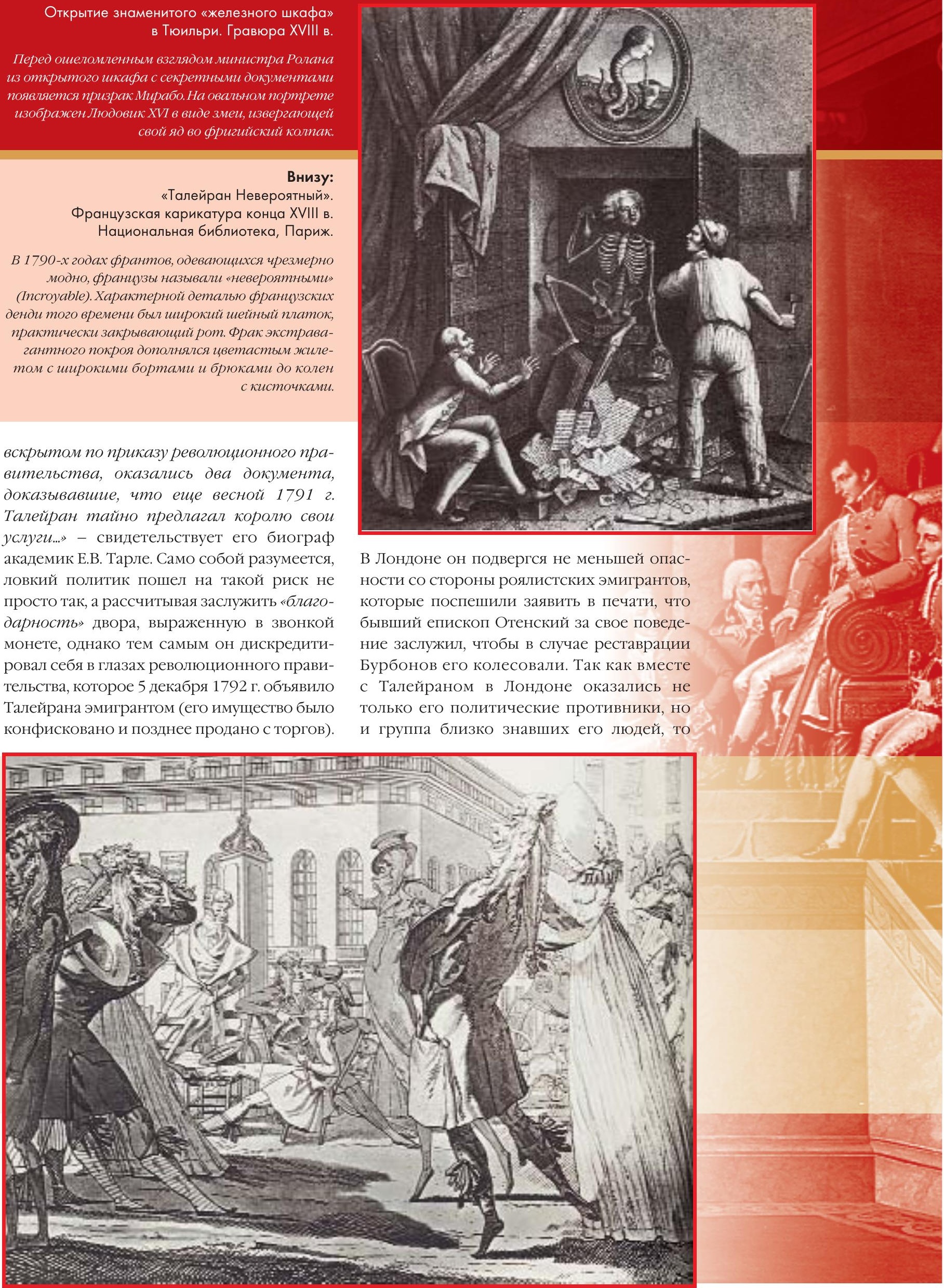

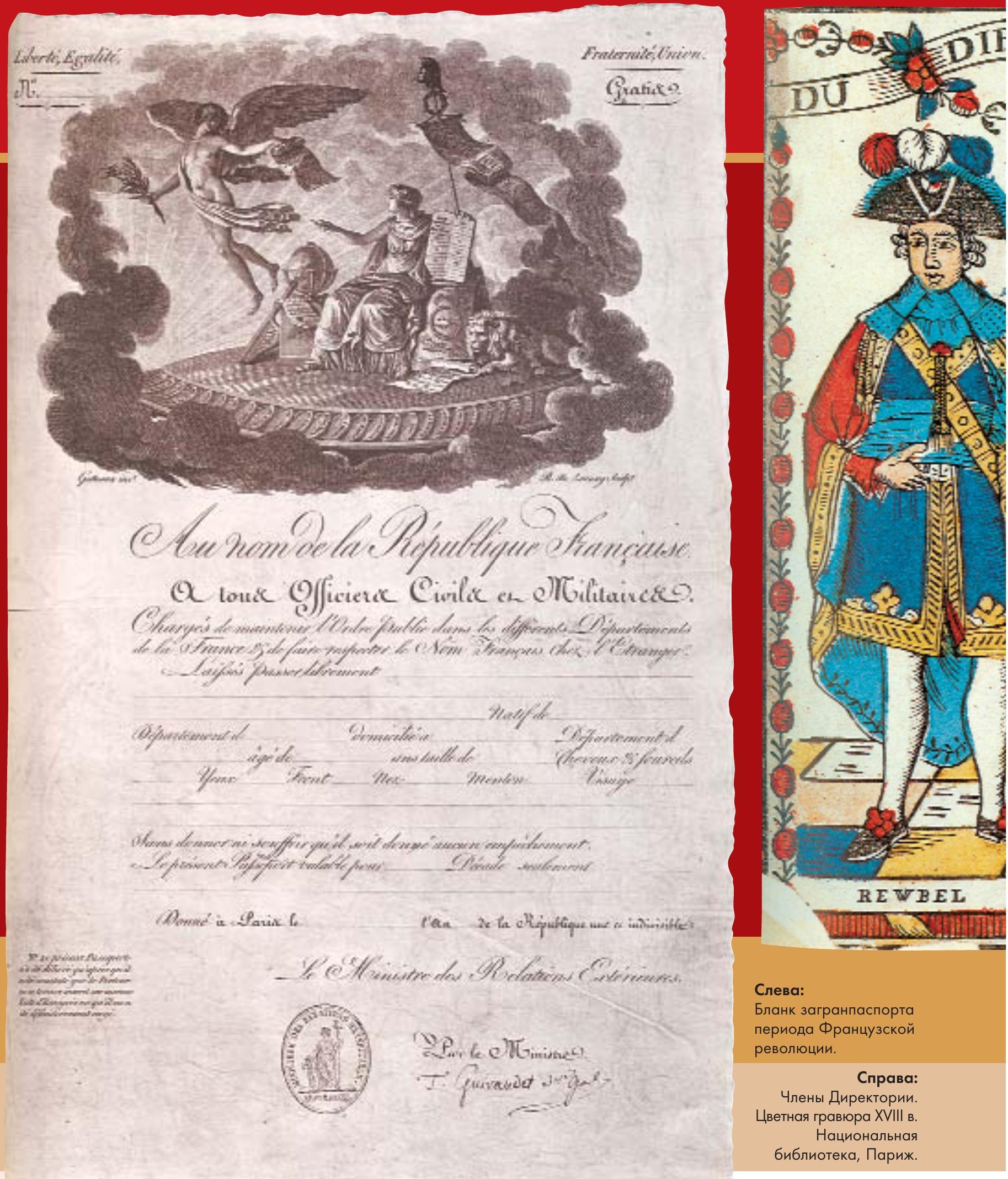

пребывание на Туманном Альбионе было для него вполне комфортным - по его словам, он даже завел знакомства среди английской политической элиты, но в начале 1794 г. был выслан из страны по приказу короля Георга III.
Талейран отправился в Соединенные Штаты Америки, но здесь противодействие французской дипломатической миссии мешало заниматься ему политической деятельностью; из крупных политических деятелей он сумел познакомиться только с минист- 


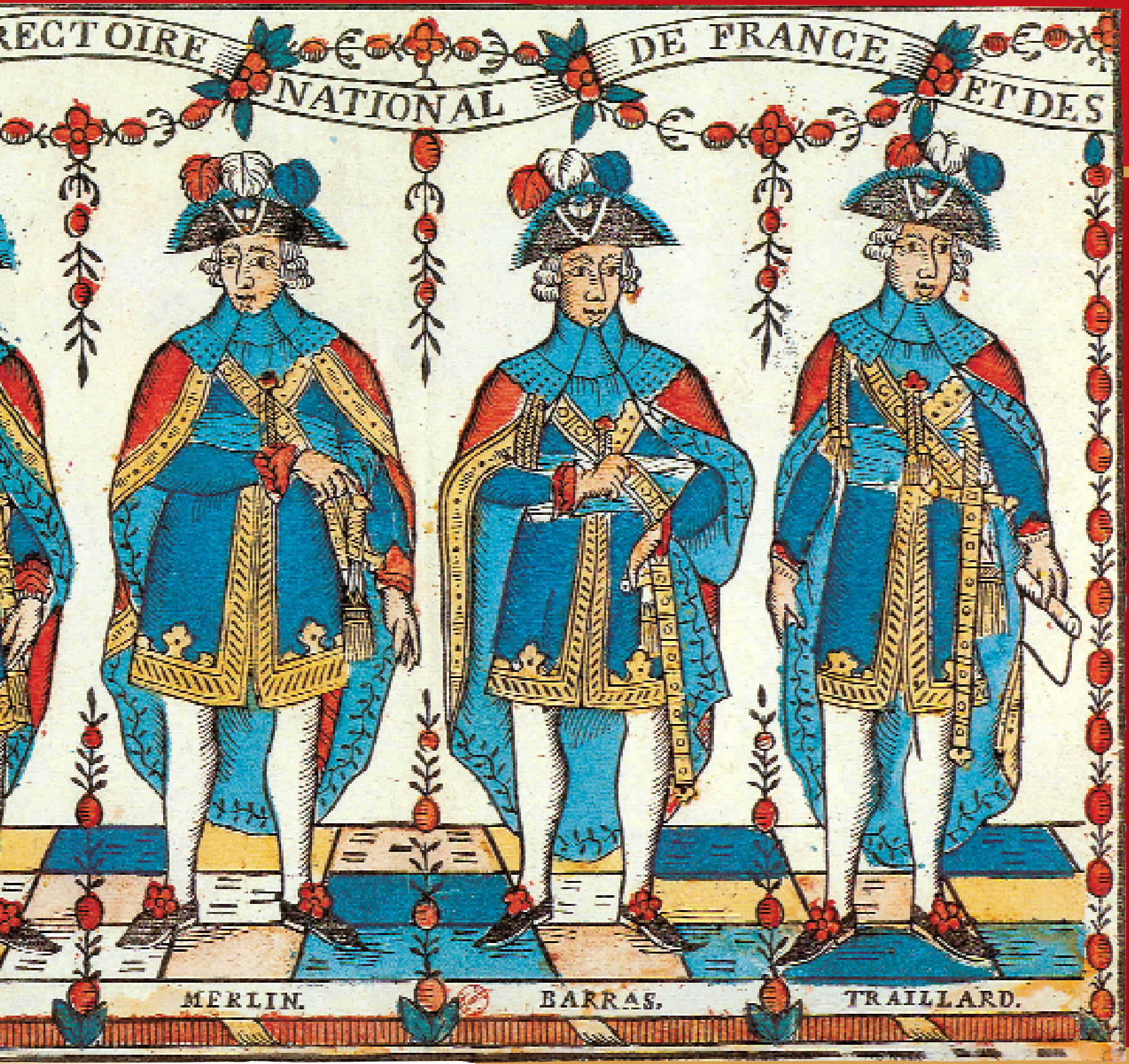

ром финансов США Александром Гамильтоном. В Новом Свете бывший епископ и революционер «переквалифицировался» и стал коммерсантом, пытаясь (впрочем, не всегда удачно) извлечь доход из различных торговых мероприятий. Тем временем во Франции пала радикальная якобинская диктатура, установленная в 1792 г., и к власти пришла умеренная буржуазия, сформировавшая новое правительство Директорию. Была организована кампания в поддержку его реабилитации, в результате которой в 1795 г.
Так как вместе с Талейраном в Лондоне оказались не только его политические противники, но и группа близко знавших его людей, то пребывание на Туманном Альбионе было для него вполне комфортным - по его словам, он даже завел знакомства среди английской политической элиты, но в начале 1794 г. был выслан из страны по приказу короля Георга III. 


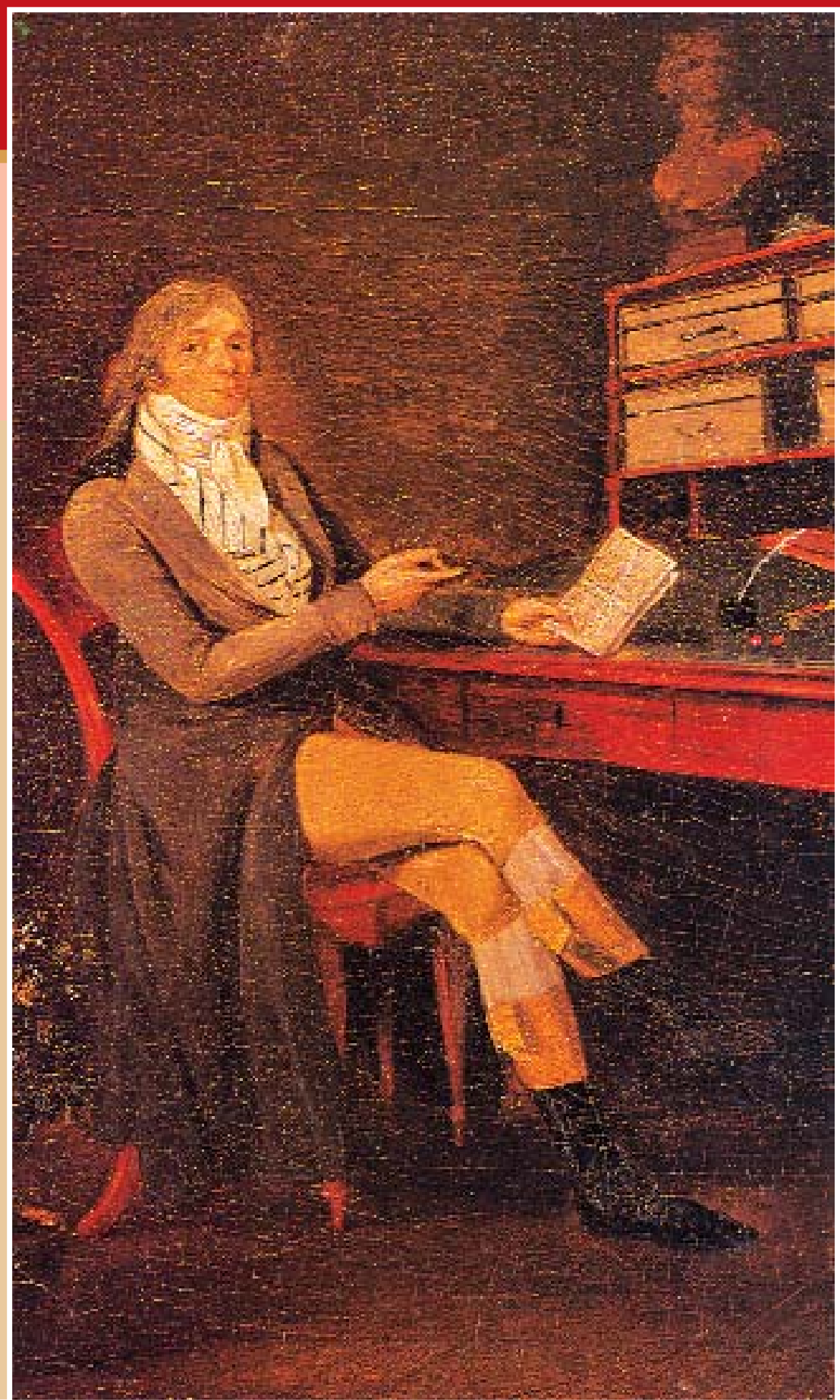

санкции в отношении Талейрана были отменены; вскоре он был заочно избран членом Института Франции, заменившим Французскую академию. В 1796 г. Талейран вернулся на родину и развернул активную общественную деятельность; примкнув к сторонникам Директории, он открыл себе путь к министерскому портфелю, несмотря на то, что перспектива видеть его в правительстве устраивала далеко не всех. Под нажимом одной из любовниц Талейрана - Жермены де
Портрет Шарля Мориса ТайлеранаПеригора. Худ. Жан Франсуа Гарнере. Конец XVIII в.

Музей Ламбине, Версаль.

\section{Сражение при пирамидах $\Rightarrow$ 28 июля 1798 года Рисунок и литография В. Адама. Середина XIX в. \\ Государственный Исторический музей,} Москва.

дела поступали к нему вполне реиенными Директорией. мне, как и ему, приходилось только наблюдать за их исполнением, но я часто задерживал их течение, что позволяло мне, переждав первый порыв членов Директории, смягчать редакцию. Помимо этого у меня не было других функции, кроме выдачи паспортов и виз». Талейран укрепил дисциплину в своей новой «епархии», но осуществить масштабные преобразования ему не дали. Даже при скромном с виду объеме административных функций, предприимчивый министр, чей годовой оклад на новом посту превышал сто тысяч ливров, умудрился злоупотребить предоставленными ему полномочиями в целях личного обогащения - он был одержим идеей составить себе «громадное состояние» и за два года пребывания в должности по утверждению Барраса «заработал» 13 млн. 650 тыс. франков. Наживаясь на тайнах «большой политики», в бытность министром, Талейран, как правило, торговал второстепенной информацией, создав целую агентурную сеть, которая помогала ему обогащаться самыми различными способами. Но очень скоро он оказался в центре громкого международного скандала. Осенью 1797 г. в Париже появилась неофициальная американская делегация, которая намеревалась купить на большую сумму ценные бумаги голландского займа; ее члены планировали поднести денежный «подарок» только членам Директории, однако им предложили дать 120 тысяч франков «на десерт» еще и министру внешних сношений Талейрану; в процессе 


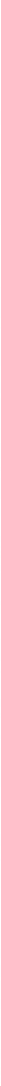

переговоров сумма выросла до 250 тысяч, но американцы упирались, тогда Талейран прибег к политическому шантажу и весной 1798 г. один из американских представителей, выехав в США, предал эту историю гласности, правда, скрыв имена посредников под инициалами X. Y. Z. В итоге Франция и США, чьи отношения и так оставляли желать лучшего, оказались на пороге войны, а Талейран - на грани отставки. Тем не менее, он сохранил свой пост, постепенно сближаясь с молодым честолюбивым генералом Наполеоном Бонапартом, удачно проявившим себя в Итальянской кампании 1796-1797 гг. К тому моменту, когда Талейран встал во главе французской дипломатии, Бонапарт уже снискал известность, и министр первый вступил с ним в переписку, а позднее принял участие в его чествовании в Париже. Уже к осени 1797 г. два политика сформировали военно-дипломатический «тандем», контролировавший мирные переговоры со «Священной
Римской империей». В 1798 г. Талейран поддержал проект Египетской экспедиции Бонапарта, призванный нанести ущерб интересам Англии, достичь соглашения с которой министру так и не удалось. По договоренности с Бонапартом Талейран должен был сменить министерский пост на пост посланника в Стамбуле, чтобы обеспечивать дипломатическое прикрытие Египетской экспедиции «с близкого расстоя- ния», но своего обещания не сдержал. В то время его больше привлекала перспектива сделаться членом Директории, однако он не смог занять ни одного вакантного места - бывшему епископу Талейрану предпочли бывшего аббата Жозефа Эммануэля Сийеса, политического идеолога «третьего сословия». К тому же Талейран разошелся с руководством республики в геополитических вопpocax, не поддерживая концепцию

Наживаясь на тайнах «большой политики», в бытность министром, Талейран, как правило, торговал второстепенной информацией, создав целую агентурную сеть, которая помогала ему обогащаться самыми различными способами. Но очень скоро он оказался в центре громкого международного скандала. 
Портрет Жозефа Эммануэля Сийеса. Гравюра Ж.-Б. Верите. Около 1792 г. Национальная библиотека, Париж.

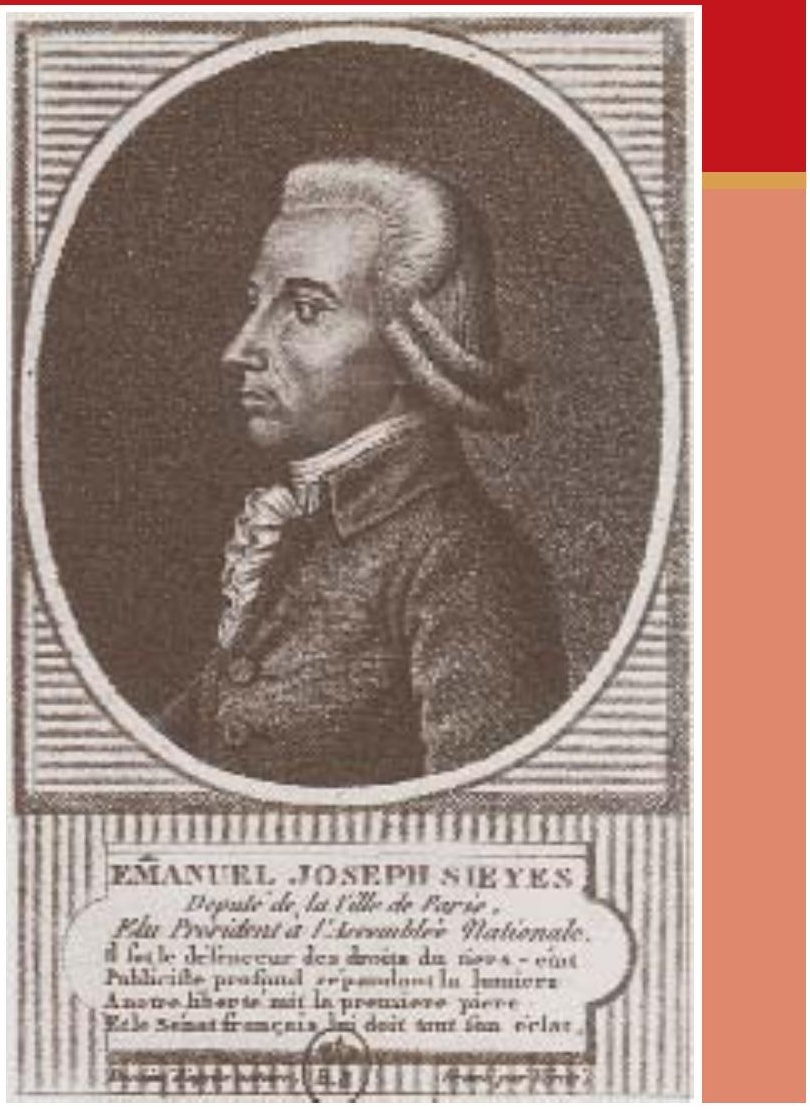

авторитетный военный, однако подходящей кандидатуры найти не смогли и все надежды были возложены на Сийеса, который, вместо того чтобы спасти режим Директории, постарался как можно быстрее его угробить. Замысел Сийеса разделял Баррас, но роль «могильщика» Директории была предназначена Бонапарту, который при попустительстве исполнительной власти сумел подготовить и осуществить восемнадцатого брюмера (9 ноября) 1799 г. государственный переворот, который был замаскирован под «конституционную реформу». Талейран был в курсе этих событий, выступал посредником между Бонапартом, Баррасом и Сийесом, изыскивал источники финансирования этого мероприятия, хотя на страницах мемуаров его роль выглядит более скромной. Именно Талейран в критический момент добился добровольной отставки Барраса, что окончательно похоронило Директорию, позволив придать законность насильственным действиям Бонапарта. Существует легенда, что в качестве «отступ-

Поль Баррас, член Исполнительной Директории. Гравюра Ж.-Б. Компанье по рисунку Ф. Бонневилля. 


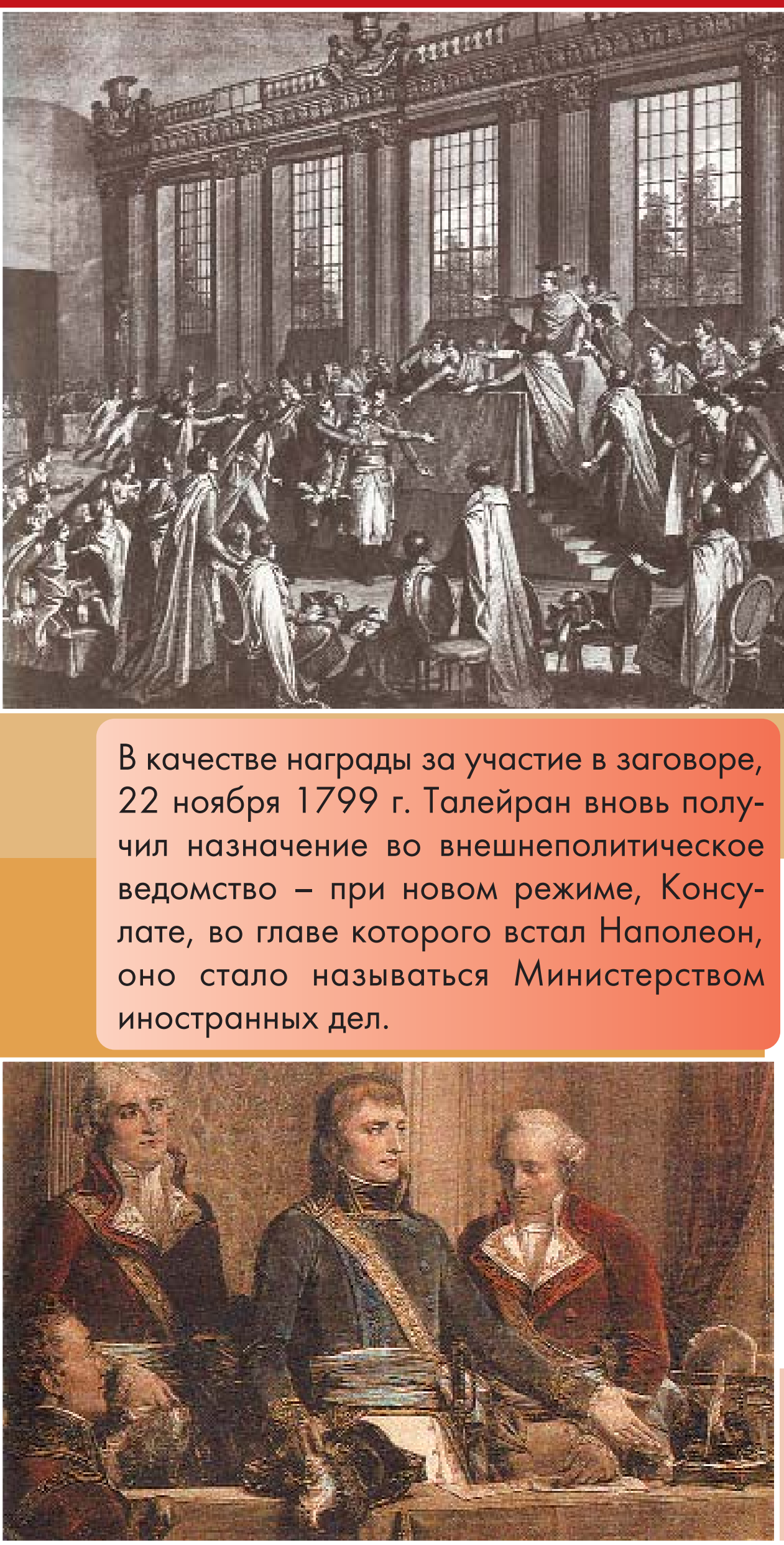

ных» от директорского кресла Талейран должен был передать Баррасу то ли один, то ли три миллиона франков, но «забыл» это сделать. В качестве награды за участие в заговоре, 22 ноября 1799 г. Талейран вновь получил назначение во внешнеполитическое ведомство - при новом режиме, Консулате, во главе которого встал Наполеон, оно стало называться Министерством иностранных дел. С именем Наполеона на ближайшие четырнадцать лет оказалась связана дальнейшая политическая карьера Талейрана. «Чтобы дать власти первого консула еше больше силы, - писал Талейран,

Второй консул Камбасерес, первый консул Бонапарт и третий консул Лебрен. Литография XIX в.

Фрагмент картины Огюста Куде «Учреждение Государственного совета в Малом Люксембургском дворце 25 декабря 1799 года». 


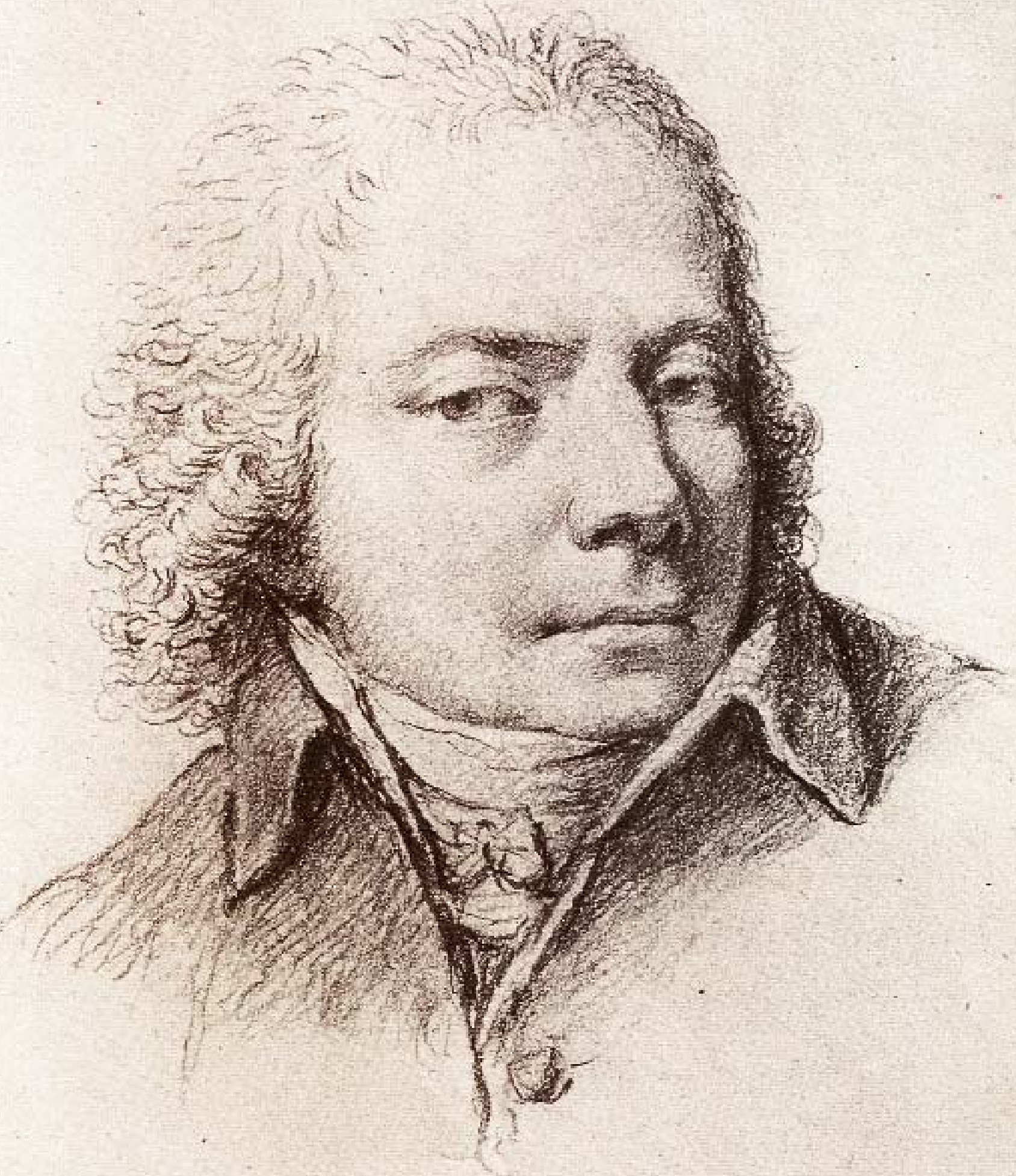


Покупка Луизианы (Наполеоновский министр внешних сношений Талейран обсуждает с американцами Джеймсом Монро и Робертом Ливингстоном последние детали соглашения по продаже

Луизианы 30 апреля 1803 года). Неизвестный художник XIX в.

тора Франца II, а общая сумма «выручки», полученной только при заключении Люневильского мирного договора в 1801 г., по подсчетам Е.В. Тарле составила около 15 млн. франков. Есть предположение, что министр иностранных дел не остался в накладе и при продаже США полученной от испанского правительства в обмен на Тоскану провинции Луизианы, которая была осуществлена весной 1803 г., вскоре после того, как французскому правительству удалось урегулировать отношения, испорченные аферой 1798 г. Писатель, публицист и политический деятель Франсуа Рене де Шатобриан, занимавший в 1803-1804 гг. пост первого секретаря французского посольства в Риме, позднее писал о Талейране: «Я обедал у него: он остался в моей памяти таким, каким предстал мне впервые. Впрочем, его прекрасные манеры нисколько не походили на манеры его

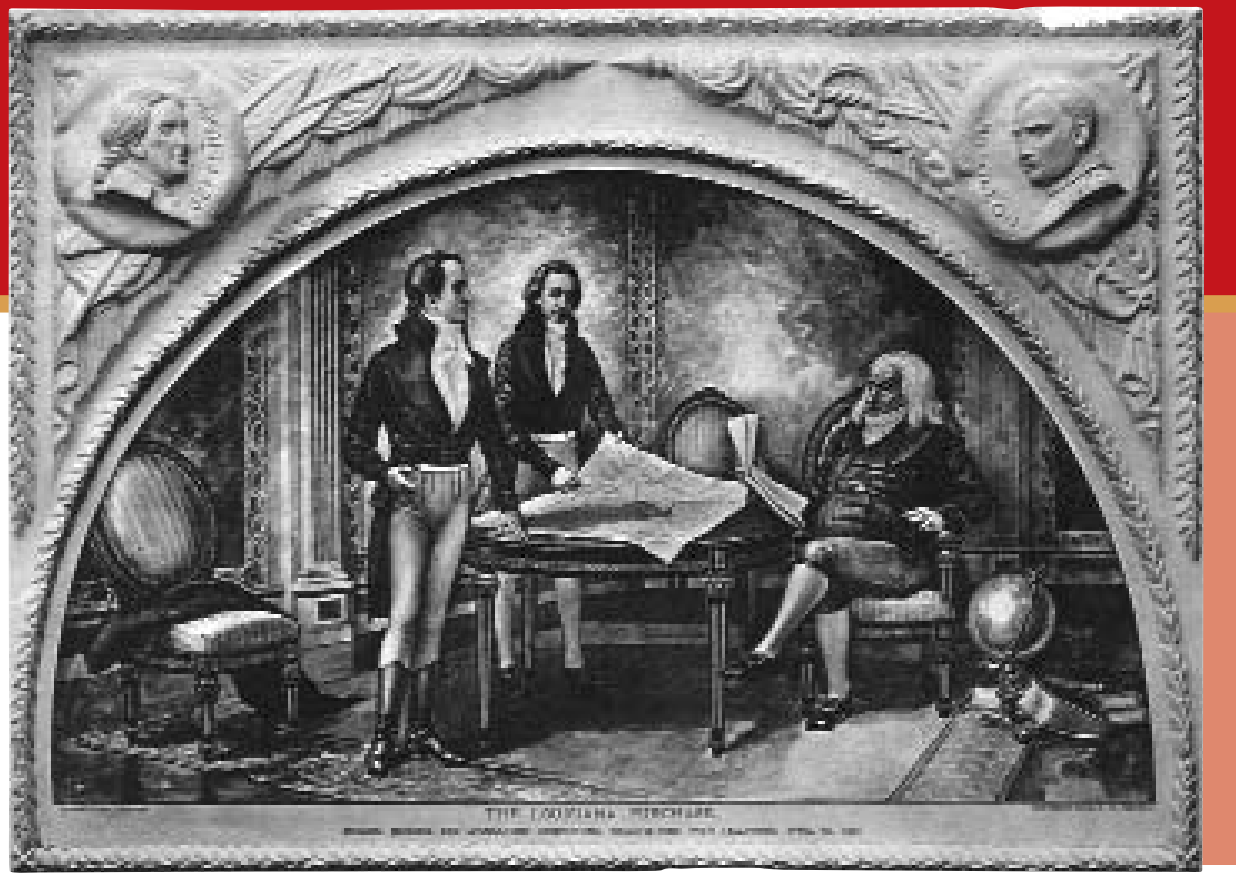

подлого окружения; его моченни чество было преисполнено непостижимой важности...”

С приходом к власти Бонапарта на пороге XIX столетия внешнеполитическое положение Французской республики стало более устойчивым. В 1800 г. были налажены контакты с русским правите льством, однако проект заключения союза против Англии остался не реализованным вследствие траги-

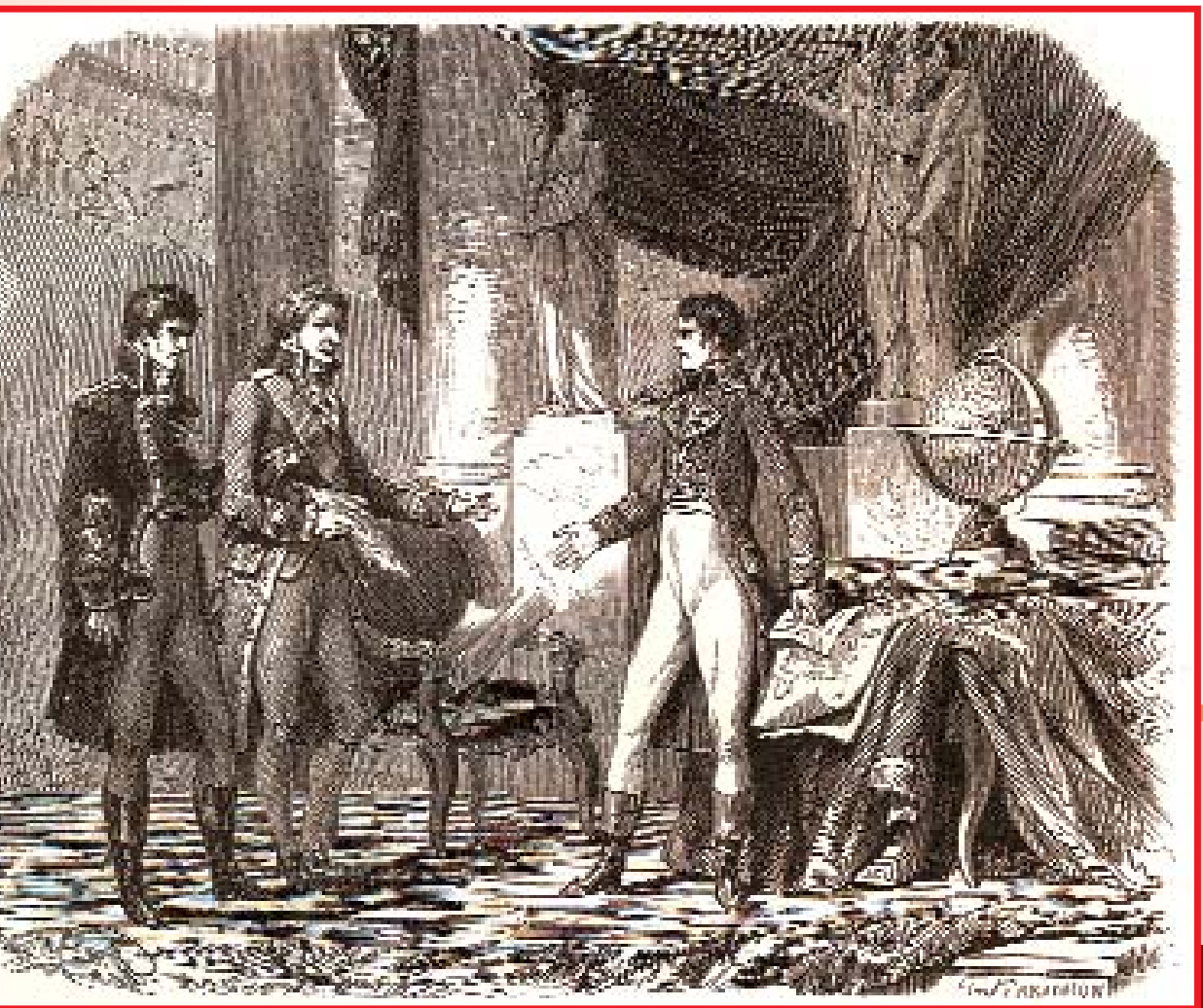

ческой гибели императора Павла I 11 марта 1801 г. - его преемник Александр I был менее расположен к режиму Наполеона, поэтому русско-французское соглашение, которое к тому моменту было уже подготовлено, состоялось только в конце 1801 г. В марте 1802 г. Талейран добился большого политического успеха, к которому стремился с тех пор как встал во главе французской дипломатии - подписания мирного договора с Великобританией. По Амьенскому миру, который при содействии Талейрана подписал старший брат Наполеона Жозеф Бонапарт, островное королевство признавало Французскую республику и созданные ею республиканские государства-сателлиты в Голландии, Швейцарии и Италии. Однако этот мир, не удовлетворявший обе стороны, оказался недолговечным - идея франко-британского сближения, над реализацией которой трудился Талейран, потерпела крах. Давая оценку этим событиям в своих мемуарах, он возлагает ответственность за неудачу своего внешнеполитического курса на Пер-

Заключение Амьенского мира 25 марта 1802 года. Гравюра XIX в. 


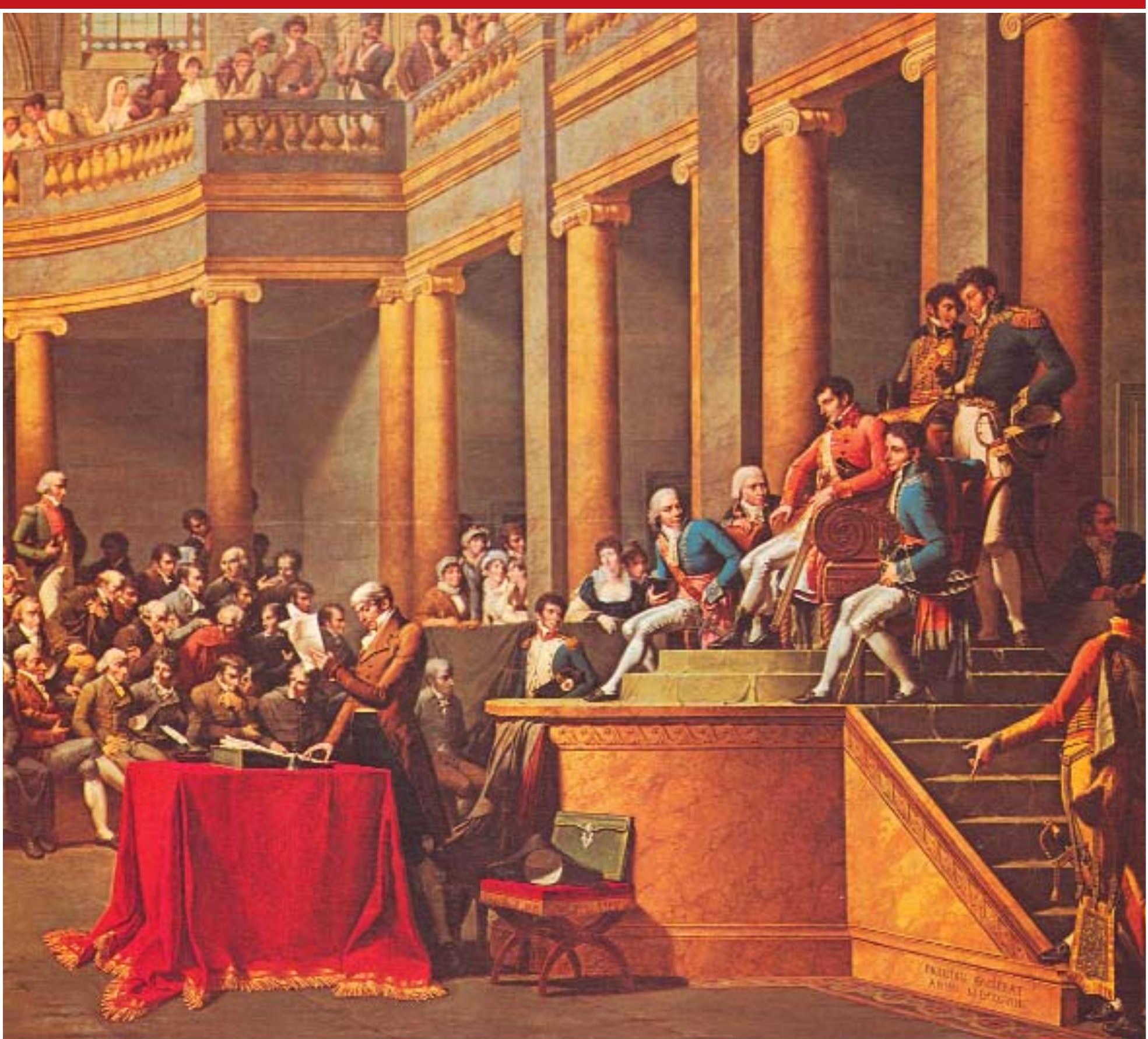

вого консула: «Едва был заключен Амьенский мир, как умеренность начала покидать Бонапарта; мир этот не получил еще полного осушествления, а он начал уже бросать семена новых войн, которые, разорив Европу и Франиию, должны были привести его самого к гибели.

Вверху: Совет Цезальпинской республики провозглашает первого консула Наполеона Бонапарта своим президентом 26 января 1802 года.

Худ. Никола Андре Монсио. 1808 г. Национальный музей Версальский дворец.
Формально денонсация Амьенского мира в мае 1803 г. исходила именно от Первого консула, который заявил на приеме дипломатического корпуса в присутствии английского посла Уинтворта: «Англичане желают войны, но если они первые обнажат меч, я последним вложу его в ножны» и добавил: «Англия не уважает договоров - ну что же! завесим их черным покрывалом...» 


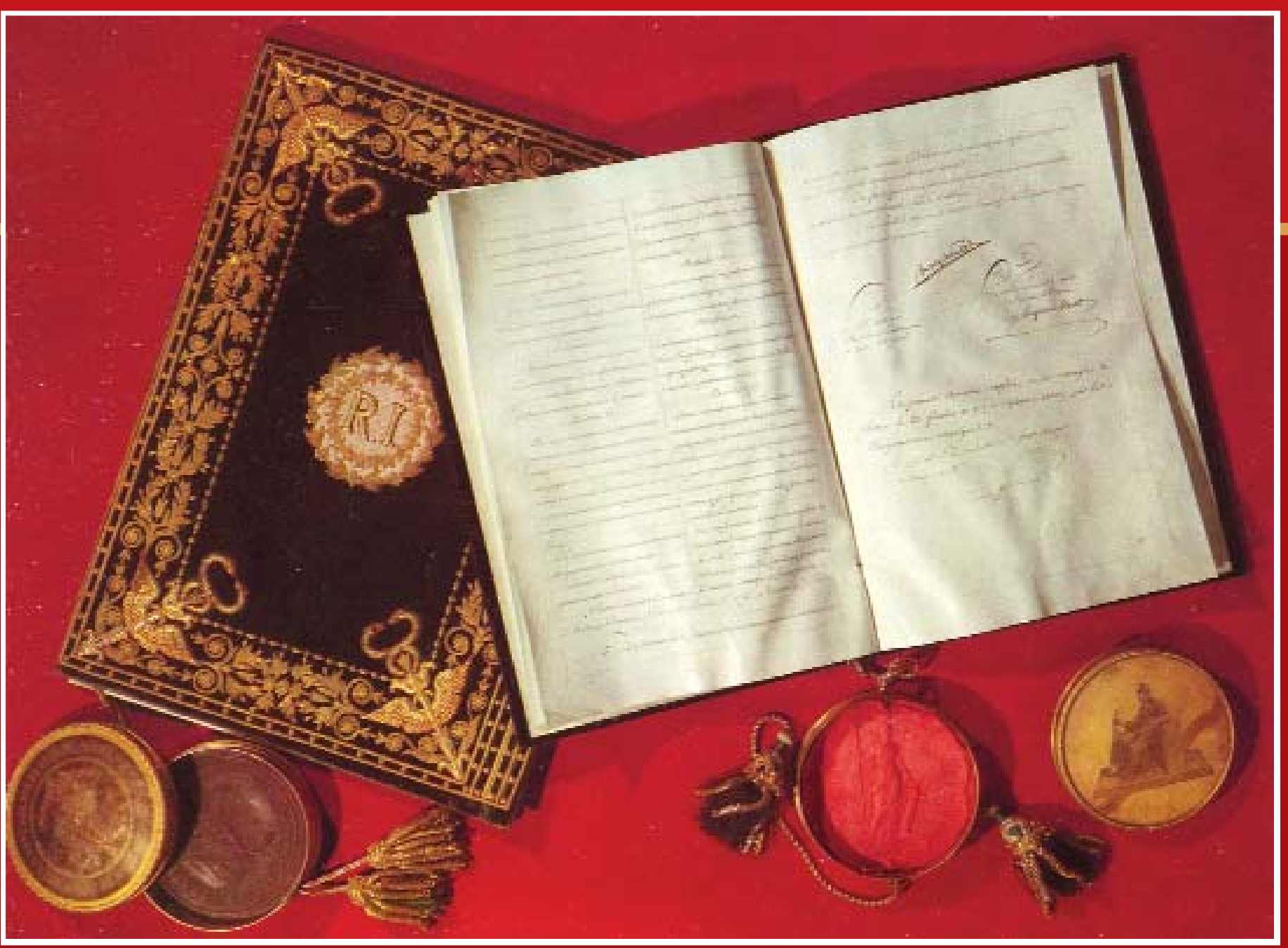

Более успешной была итальянская политика Талейрана. В 1803 г. он подготовил избрание Наполеона президентом Цизальпинской (Итальянской) республики, а также способствовал урегулированию отношений Французской республики с папством.
Конкордат, подписанный между папским престолом и Французской республикой. 1801 г.

Библиотека Ватикана, Рим.

Подписание конкордата. Раскрашенная гравюра XVIII в. Музей Карнавале, Париж.

№1 - Жозеф Бонапарт, №2 - кардинал Консальви, №3 - архиеписком Спина, №4 - Kрете, №5 - аббат Бернъе, №6 - Казелли.
Пьемонт должен был быть возвращен королю Сардинии немедленно после заключения Люневильского мира: он лишь временно находился в руках Франщии. Возврамение его было бы одновременно актом бесспорной справедливости и проявлением весъма мудрой политики. Бонапарт же, наоборот, присоединил его к Франщии. Я делал напрасные усилия, чтобы отклонить его от этого иага. Он считал, ито это в его личных интересах, ему каза- лосъ, что этого требует его самолюбие, и оно взяло перевес над всеми соображениями осторожности...

Аналийское правительство, заключившее мир только по необходимости, справилось с внутренними осложнениями, которые сделали для него этот мир почти неизбежным, но не возвратило еше Мальты; желая сохранить ее, оно воспользовалось случаем, который представило ему присоединение Пьемонта к Франции, и возобновило военные действия...” Разумеется, Талейрану было легко перекладывать задним числом всю ответственность на Наполеона; в данном случае мы имеем дело с ретроспективно сложившейся концепцией, однако, нет сомнений в том, что формально денонсация Амьенского мира в мае 1803 г. исходила именно от Первого консула, который заявил на приеме дипломатического корпуса в присутствии английского посла Уинтворта: «Англичане жела- 


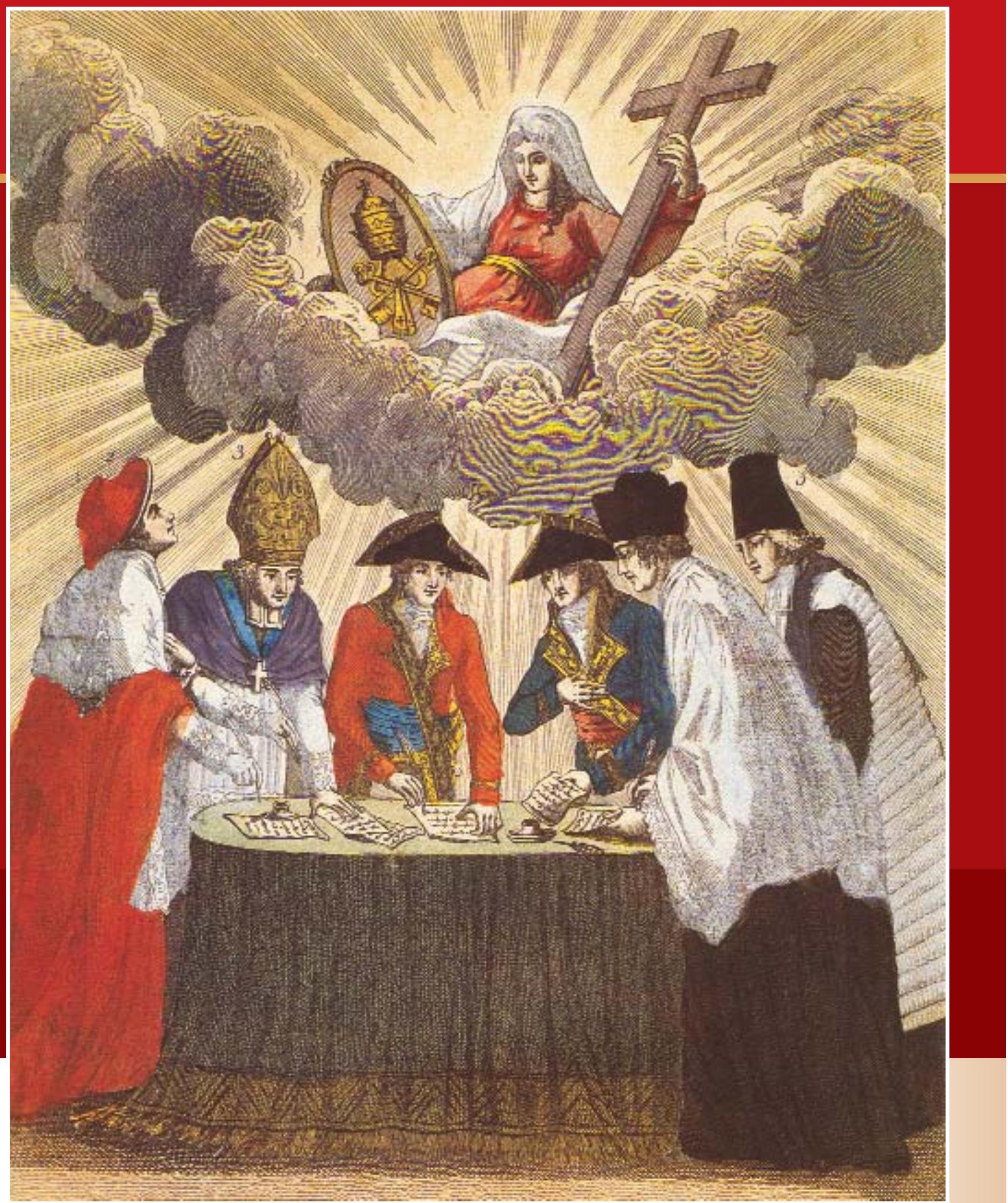

ют войны, но если они первые обнажат меч, я последним вложу его в ножнь» и добавил: «Англия не уважает договоров - ну что же! завесим их черным покрывалом...” Впрочем, до немедленного откры- тия военных действий дело не дошло - вместо этого на протяжении двух лет (вплоть до Трафальгарской битвы 1805 г.) англо-французское противостояние, как удачно выразился историк А.3. Манфред, напоминало «поединок льва и кита»: «Франиия не имела флота, чтобы поразить Англию на море. Британия не имела армии, чтобы одолеть Францию на суме. Один на один они оставались недосягаемы друг для друга». 


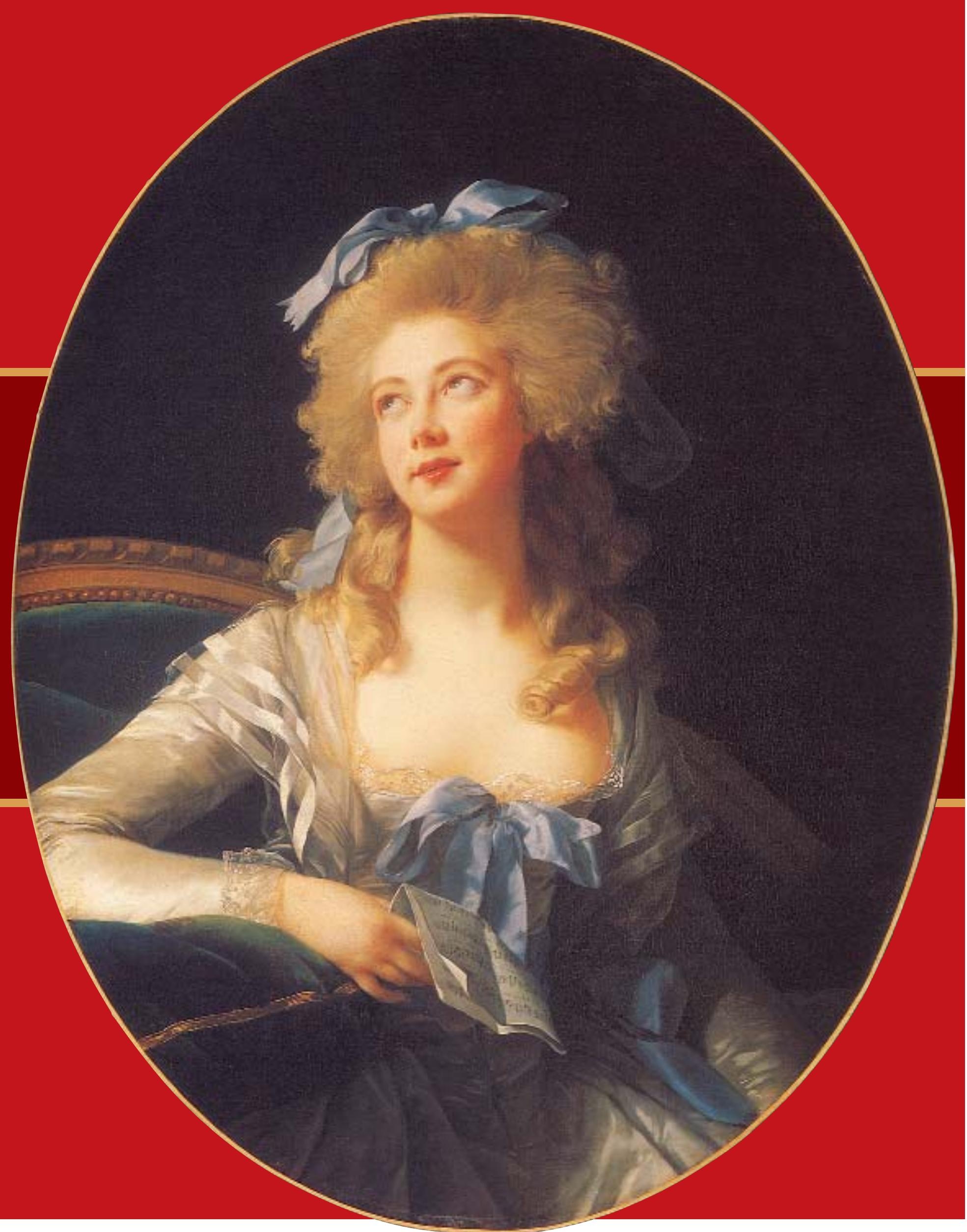


Портрет мадам Грант. Худ. Элизабет Виже-Лебрен. 1783 г.

Музей Метрополитен, Нью-Йорк.

Картин Ноәлла Ворле (1762-1834 гг.) родилась в семъе франиузского офицера в колониальных владениях в Индии. В 16 лет в Калькутте она выила замуж за британского чиновника Джорджа Френсиса Гранта. После короткого, но весъпа скандального, романа с политиком сэром Филипом Фрэнсисом (прославивииися ожесточенной критикой первого генерал-губернатора Индии Уоррена Гастингса), семейная жизн мадам Грант дала трешину, и она уехала в Париж. Кмоменту написания портрета Виже-Лебрен мадам Грант уже стала одной из самъи известных куртизанок Парижа. В 1789 году, иудом избежав гибели во время резни на улииах Парижа, она бежсала в Анллию. После падения Робеспьера, несмотря на то, что ее имя фигурировало в списке әмигрантов, мадам Грант вернулась во Францию влесте со своим любовником, генуэзцем М. Спинола. Оба были сразу же арестованы, Спинола депортирован, а мадам Грант отппущена, но осталась под надзором полици. Во время Директории она была заключена в тюриму по обвинению в итионаже. Очарованнъй ею Ш.-М. Талейран обратился за помощью к Баррасу: «Она долго жила в Инди, оченъ красивая, оченъ ленивая, самая пустая жениина, какую я только знал. От ее имени я проиу Вас проявить интерес кее делу». Позднее и художниа Виже-Лебрен отмечала скудные умственные способности этой красивой жениины: «...мадам Талейран была не слииком умной, но ума ее второго мужс слихвой хватало на двоих. В статусе любовнищы Талейрана мадам Грант прожила в официальной резиденции министра до 1802 года, когда они вынуждены были пожениться по настоянию Наполеона. После регистрачии отноиений пара довольно быстро разъехаласъ, хотя Катрин продолжсла выполнять обязанности жены министра. От прежней страсти Талейрана остались одни угли, к тому же Катрин сильно растолстела, что не добавляло ей привлекательности. Такая ситуация продолжаласъ до тех пор, пока Талейран не отправился на Венский конгресс в сопровождени герцогини Курляндской и ее дочери. Возмуценная откровенньи пренебрежением, мадам Талейран уехала в Лондон, а затем перебралась в Брюссель. Денег, которые выплачивал ей муж, вполне хватало на роскоинуюо жизнь. В последние годы жизни Катрин Талейран-Перигор, княгиня Беневентская провела в Париже, где и скончаласъ 10 декабря 1834 года.

Более успешной была итальянская политика Талейрана. В 1803 г. он подготовил избрание Наполеона президентом Цизальпинской (Итальянской) республики, а также способствовал урегулированию отношений Французской республики с папством. В мемуарах Талейран писал об этом так: «Со времени битвы при Маренго (в 1800 г. - Д.Б.) между Бонапартом и римским двором завязались тайные сношения. Он имел в Милане несколько совешаний с посланником папы Пия VI, избранного в Венеции преемником Пию VI; совещания эти послужили отправным пунктом конкордата, подписанного позднее в Париже кардиналом Консальви. Это согламение и его немедленная ратификация прими-

Мадам Талейран, при Директории сидевшая в тюрьме по обвинению в шпионаже, быстро освоила «бизнес» мужа - она за деньги оказывала политическую протекцию, торговала политическими секретами, к ее услугам прибегали финансисты, иностранные дипломаты и аристократы; не будет преувеличением сказать, что чета Талейранов открыла своего рода «семейную фирму».

рили Францию с папским престолом; оно встретило оппозицию только со стороны некоторых военных, весыла честных, впрочем, людей, ум которых не мог, однако, возвыситьса до такого рода понятии. После этого великого примирения с церковъю, которому я в сильней-

Портрет Анны Шарлотты Доротеи, герцогини Курляндской. Худ. Марчелло Баччарелли. XVIII в.

Анна Шарлотта Доротея, урожденная графиня фон Медем, в браке герцогиня Курляндская (1761-1821 гг.) происходила из старого курляндского дворянского рода. Одним из ее предков был Конрад фон Медем, гроссмейстер Ливонского ордена, основавиий замок в Митаве. Ее сестра Элиза (в замужестве баронесса фон дер Рекке) стала известной писательнищей и поэтессой. Слава о прекрасных сестрах фон Медем ила по всей Курляндии, их называли «рекрасная Доротея и умная Элиза». 6 ноября 1779 года Доротея фон Медем стала третьей женой Петера фон Бирона, герцога Курляндского и Земгальского. Благодаря своей красоте и родословной Доротея была вхожа в высиие круги европейского дворянства, поэтолу муж часто посылал ее с различными «диломатическими миссиями в Вариаву, Берлин, Карловы Вары и Санкт-Петербург. К 1790-м годам отноиения между супругами разладились, и гериогиня переехала в Курляндский двореи в Берлине, где держала аристократический салон. Вскоре новыи жрибежищем муз герцогини Курляндской стало ее имение Лёбихау в Альтенбурге. Примерно в те же годы герцогиня Курляндская становится любовнищей Талейрана, под влияниеи которого портятся ее отношения с Наполеоном. Во время Венского конгресса она виесте с дочерими живет в доме Талейрана. Вскоре место гериогини Курляндской около Талейрана занилает ее младиая дочь Доротея. Похожая история произоила чуть раньие, в 1800 году, когда стариая дочь Вильгельмина, герцогиня Саган влюбилась в тогдапнего любовника своей. матери шведского генерала Густава Армфельта и даже родила от него дочъ. Интересно, что в 1813 году у Вильгельмины Саган начался раман с Клеменсам фон Меттернихом, многолетнии политическии союзником Талейрана. Анна, герцогиня Курляндская умерла в 1821 году в своем имении Лёбихау. Впоследствии ее прах был перенесен в фамильный склеп в залке Саган.

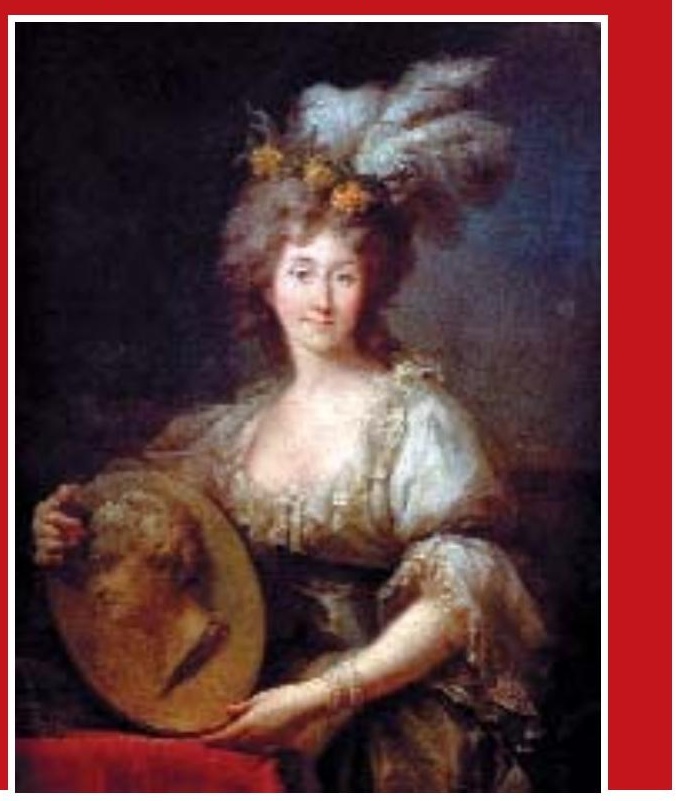




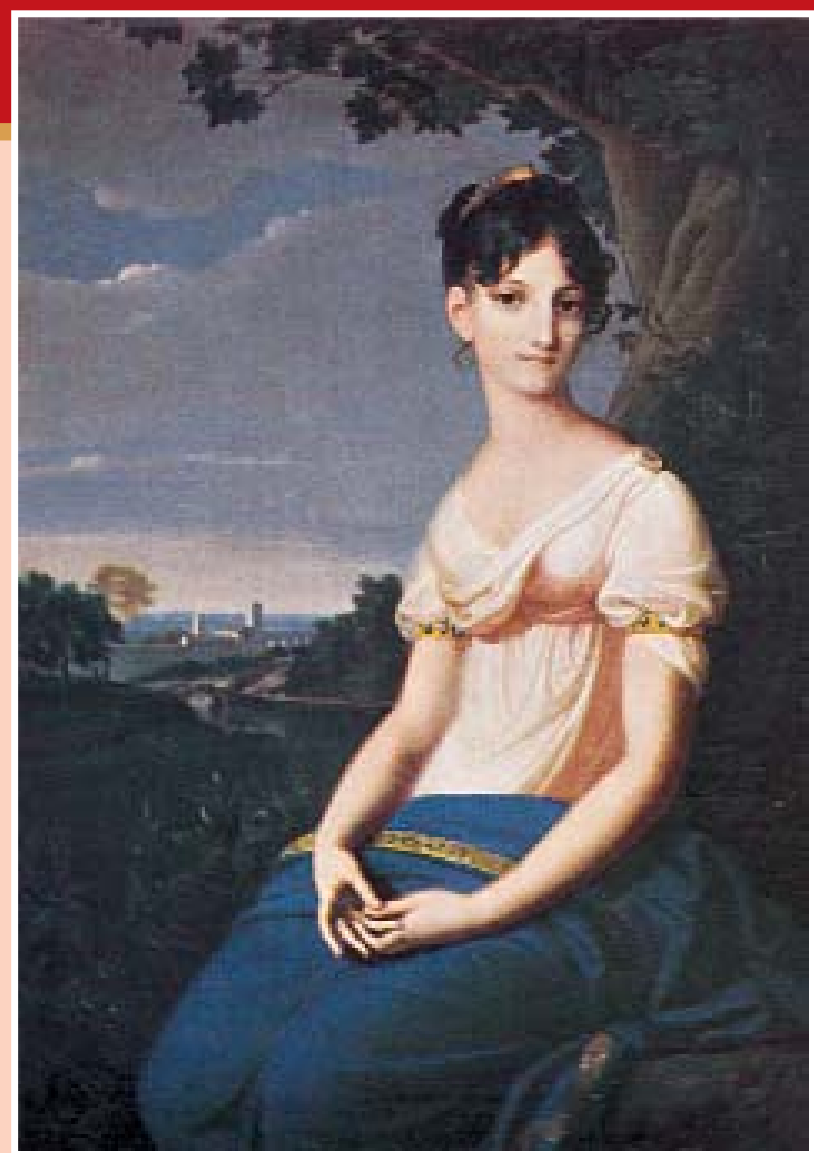

Портрет Доротеи фон Бирон, будущей герцогини Дино. Неизвестный художник. Около 1810 г.

Замок Валансе.

Доротея фон Бирон, гериогиня Дино (1793-1862 г2.), младиая дочъ курляндского гериога Петера фон Бирона и его третъей жены Анны Доротеи фон Медем, герцогини Курляндской (настоящим отиом Доротеи, скорее всего, был польский граф Александр Батовский). ШШ.-М. Талейран, любовник ее матери, искал для своего племянника богатую и титулованную невесту, и с одобрения Наполеона в 1809 году организовал бракДоротеи и Эдмона Талейран-Перигора (1787-1872 г2.) Брак не был счастливым, что, правда, не помешало появлению троих детей (правда, дочь Доротея умерла в возрасте 2 лет). Во время Венского конгресса Доротея начинает играть больиую роль в жизни Ш.-М. Талейрана, предполагают, что примерно в 1815 году он делает ее свой любовнищей и негласной хозяйкой дома. 31 августа 1817 года Талейран получает от Людовика ХИІІІ титул гериога и пэра Франции, а 2 декабря от короля Обеих Сицилий Фердинанда I - гериогство Дино (в Калабрии). Титул герцога Дино Талейран сразу же передает своему племяннику, поэтому Доротея становится гариогиней Дино. 24 марта 1818 года гериог и гериогиня Дино приняли решение о раздельном проживании, хотя официальный развод был оформлен только б ноября 1824 года. 3 июля 1820 года Талейран вместе с гериогиней Дино уезжает из Париже в Валансе. 29 декабря Доротея родила дочь Полину, отиом которой считается ШІ.-М. Талейран.Дальнейшая личная жизнь гериогини Дино была столь же бурной. Она имела репутациюо роковой женщины и родила еще трех незаконных дочерей от разных любовников. Одна из ее дочерей впоследствии стала известной чешской писательницей Боженой Немиовой (1820-1862 гг.) Доротея, гериогиня Дино жила с Талейраном в Лондоне, куда он был направлен в качестве посла. После его смерти она перебралась в замок Саган в Нижней Силезии, где и скончалась 19 сентября 1862 года.

шей степени способствовал, Бонапарт получил от папы послание касательно моего перехода в светское состояние. Послание это датировано в рииском Святом Петре 29 июня 1802 года. Мне думается, что снисходительность ко мне Пия VII добавлял политик, - лучше всего выразилась в словах, сказанных им однажды кардиналу Консальви: «Господин Талейран! да! да! Да пребудет его душа с богом, я его очень люблю!» Однако, создавая столь благожелательную картину, Талейран умалчивает о некоторых весьма существенных деталях. Положение министра-епископа оказывалось двойственным, поскольку вот
Настояв на устранении герцога, министр окончательно (как он тогда полагал), разорвал связь со «Старым режимом». Это обстоятельство поставило министра в крайне щекотливое положение после Реставрации Бурбонов, когда обвинения в адрес Талейрана стал выдвигать генерал Савари, но мастер интриги не преминул создать легенду о том, какие усилия он тайно прилагал, чтобы спасти герцога, и позаботился, чтобы она дошла до ушей принца Конде. уже на протяжении десяти лет он был отлучен от церкви, но не лишен сана священника и с введением Конкордата 1801 г., продолжая формально принадлежать к католическому духовенству, невольно оказывался в зависимости от папы римского. К тому же Наполеон стал настаивать на том, чтобы Талейран либо узаконил отношения со своей очередной любовницей Катрин Гран, либо прогнал ее, так как ее полуофициальное положение дискредитировало министра в дипломатических кругах. Однако брак епископа противоречил канонам католической церкви, а папа (вопреки заверениям Талейрана!) упорно отказывался лишить его духовного звания и дать разрешение на брак; вышеупомянутое послание позволяло ему лишь вести светский образ жизни и заниматься политической деятельностью (то есть тем, чем Талейран спокойно занимался и без папского разрешения!) Тогда в Париже решили воспользоваться этим обстоятельством и довести дело до конца в одностороннем порядке - 20 августа 1802 г., якобы на основании папско- 
Портрет Полины Талейран-Перигор Худ. Клод Мари Поль Дюбюф. 1840 г.

Замок Рошекотт.

Жозефина Полина Талейран-Перигор (1820-1890 г2.) официально считалась дочерью Эдмона Талейрана-Перигора, но его всесильный дядя с самого рождения выказывал к девочке необычайную привязанность, называя "домапним ангелом", поэтому практически никто не сомне вался в истинном отиовстве. В 1839 году Полина вышла замуж за Анри де Кастеллана, стариего сына мариала Кастеллана. Овдовев в 1847 году, остаток жизни она провела в залке Рошекотт, которыи получила в подарок от своей матери.

го послания, консулы Французской республики Бонапарт, Камбасе́рѐс и Лебрен объявили о переходе Талейрана в «гражданское состояние»; через три недели состоялись гражданская, а затем и церковная церемония бракосочетания, о чем Пий VII, направляя документы Талейрану, не мог даже помыслить. Мадам Талейран, при Директории сидевшая в тюрьме по обвинению в шпионаже, быстро освоила «бизнес» мужа - она за деньги оказывала политическую протекцию, торговала политическими секретами, к ее услугам прибегали финансисты, иностранные дипломаты и аристократы, так что не будет преувеличением сказать, что чета Талейранов открыла своего рода «семейную фирму». Правда, эта алчная и честолюбивая особа обладала скверным характером, так что умудрилась поссориться с Наполеоном - доступ ко двору оказался для нее закрыт. В конце концов, ее брак с Талейраном распался. Вокруг министра появлялись другие женщины. Некоторое время он поддерживал отношения с герцогиней Курляндской, а с 1814 г. с ее дочерью Доротеей (герцогиней Дино), вышедшей замуж за племянника князя, но позднее расставшейся с ним. Согласно легенде, одним из внебрачных сыновей министра был известный французский художник XIX в. Эжен Делакруа.

Весной 1804 г. Талейран оказался в центре громкого скандала, связанного с похищением и казнью герцога Луи Антуана Анри Энгиенского -

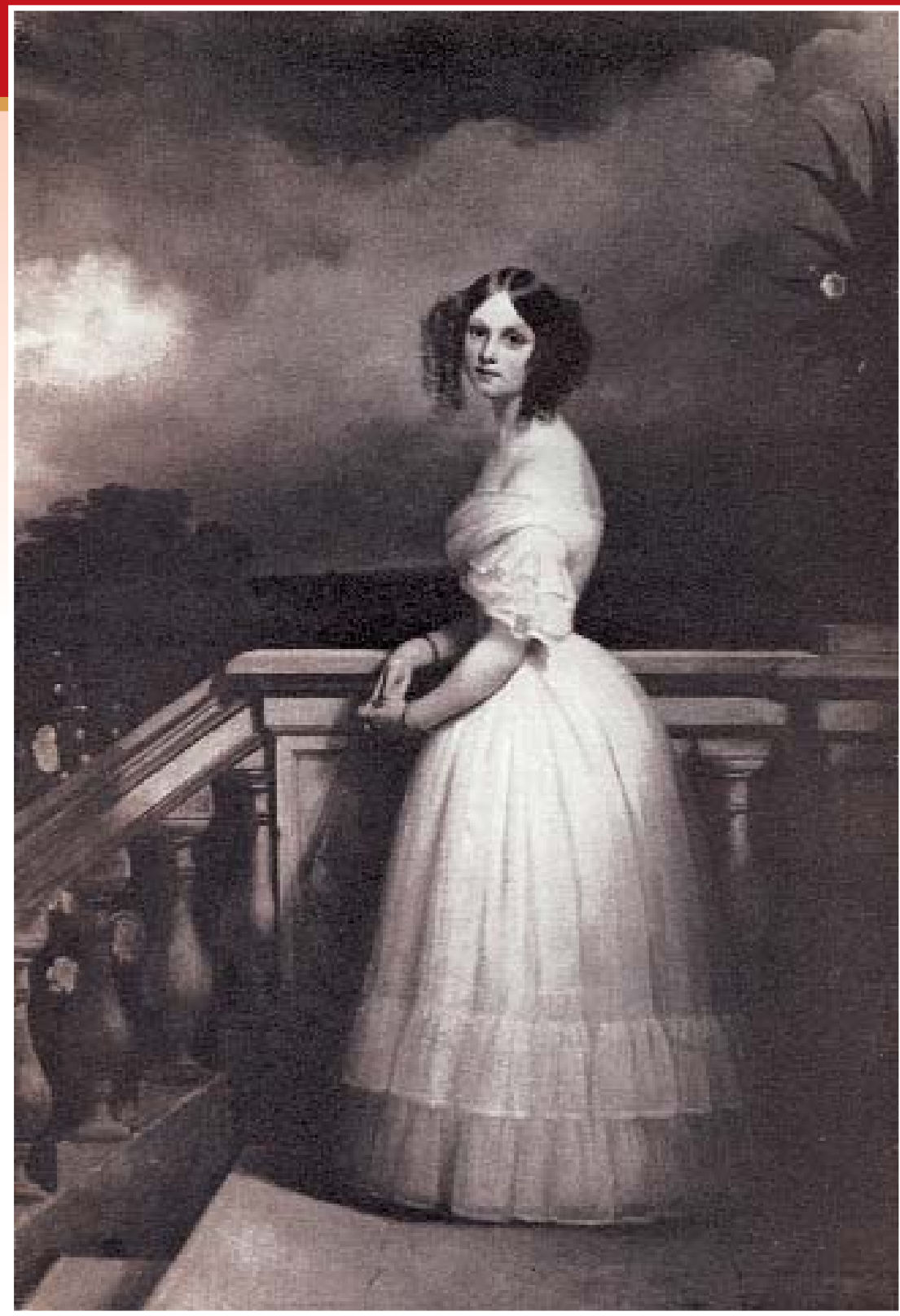

представителя ветви Бурбонов-Конде, который был обвинен в причастности к подготовке заговора против Бонапарта, организатором которого стал один из лидеров роялистов Жорж Кадудаль при содействии опального революционного генерала Шарля Пишегрю. Министр организовал дипломатическое прикрытие акции, в результате которой герцог был арестован французскими жандармами на территории Бадена и вывезен во Францию, где военный трибунал, собравшийся в Венсеннском замке, приговорил ни в чем не повинного аристократа к расстрелу (21 марта 1804 г.) Перед казнью герцог направил Наполеону прошение о помиловании, но оно было задержано и попало в руки адресата лишь через два дня после казни. Настояв на устранении герцога, министр не только превратил его казнь в акцию устрашения роялистов, но и окончательно (как он тогда полагал), разорвал связь со «Старым режимом». Это обстоятельство поставило министра в крайне щекотливое положение после Реставрации Бурбонов в 1814 г., когда обвинения в адрес Талейрана стал выдвигать другой руководитель этого рал Савари, но мастер интриги не преминул создать легенду о том, какие усилия он тайно прилагал, чтобы спасти герцога от расстрела и позаботился, чтобы она дошла до ушей принца Конде. Но это произошло много позже, а в 1804 г. Талейран «показательного процесса» - гене- 


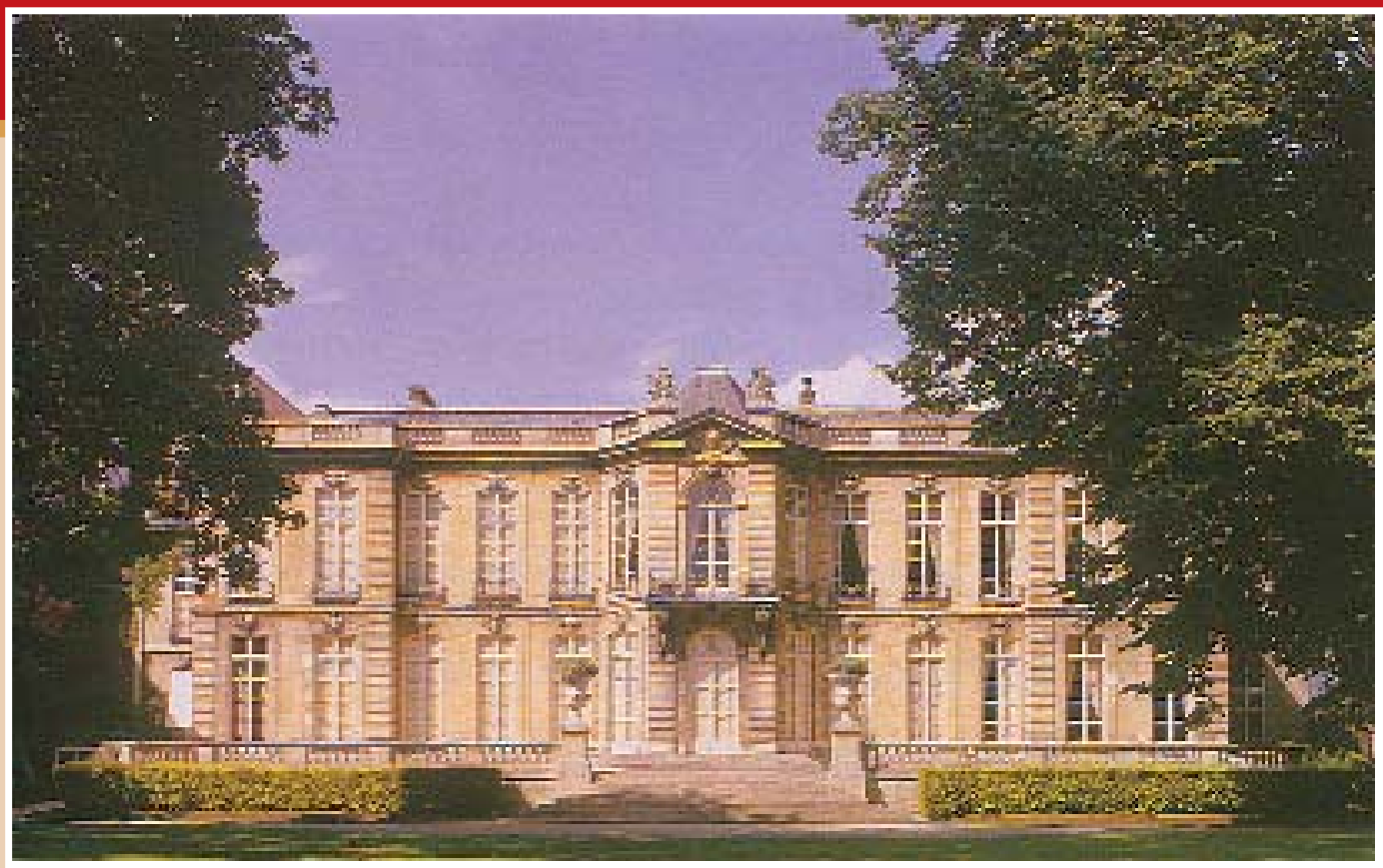

Матиньонский

дворец в Париже.

Современный вид.

Коронация $\rightarrow$ императора

Наполеона I и императрицы Жозефины в соборе Парижской Богоматери

2 декабря 1804 года. Фрагмент.

Худ. Жак-Луи Давид. 1805-1807 гг. Лувр, Париж.

В нижнем правом углу картины изображен ШІ.-М. Талейран.Его легко можно узнать по характерному профилю и красной мантии парадного костюма великого камергера». получил в награду за проявленные им усилия в разоблачении «заговора герцога Энгиенского» орден Почетного легиона. Уже для современников вина Талейрана являлась очевидной, - например, Шатобриан писал: «...Опираясь на то, что сказал Наполеон на Святой Елене и то, что, вероятно, излагал в своих писынах епископ Отенский, можно было бы доказать, что вина господина де Талейрана велика; однако не стоит выходить за рамки достоверности. Трудно отрицать, что господин де Талейран подви́ Бонапарта на роковой арест, вопреки советам Камбасе́рѐса. Но также трудно допустить, что он предвидел результат своих действий... Этот акт привел к масштаб- ным политическим последствиям, с одной стороны, способствовавшим формированию третьей антифранцузской коалиции европейских держав, а с другой - ускорившим трансформацию Консулата в империю, которая была провозглашена 18 мая в соответствии с постановлением Сената и результатами проведенного на его основании плебисцита. 2 декабря 1804 г. в соборе Парижской Богоматери в присутствии папы Пия VII (переговоры с которым вел, разумеется, министр иностранных дел) состоялась торжественная коронация Наполеона I. В специальном циркуляре человек, когда-то возвестивший миру о свержении Бурбонов, теперь писал, что «nомазание и коронование его импера-
«... «Как же так, Талейран, положа руку на сердце, сколько вы нажили за счет меня?» - однажды сказал ему в хорошем расположении духа Наполеон. На другой день, находясь в еще более прекрасном настроении, он продолжал: «Господин Талейран, скажите, что вы сделали для того, чтобы стать таким богатым?» «Сир, средство было очень простое» - ответил Талейран...» торского величества окончило револющию». Талейран занял одно из ключевых мест при императорском дворе, получив звание «великого камергера». Талейран вел образ жизни, соответствующий его положению: он стал крупным землевладельцем, приобрел несколько особняков, Матиньонский дворец в Париже (сейчас это резиденция премьер-министров Французской Республики), роскошный замок в Валансе (причем, ухитрился купить его в основном за государственный счет как место для проведения дипломатических приемов). Биограф Талейрана, известный публицист середины XIX в. Шарль Огюстен де Сент-Бёв, описал такой диалог: «Как же так, Талейран, положа руку на сердие, сколько вы нажили за счет меня?" - однажды сказал ему в хорошем расположении духа Наполеон. На другой день, находясь в еще более прекрасном настроении, он продолжал: «Господин Талейран, скажите, что вы сделали для того, чтобы стать таким богатым?» «Сир, средство было очень простое - ответил Талейран: - я купил акции государственной ренты накануне 18-го брюмера и продал их на следуюоий день». Сент-Бёв резюмировал: «Лис со свойственным ему умением изворачиваться, вырвался из когтей льван. 


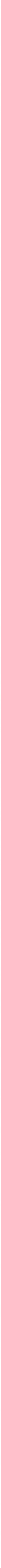

